\title{
Breathing Life into the Union's Common Values: On the Judicial Application of Article 2 TEU in the EU Value Crisis
}

\author{
Luke Dimitrios Spieker*
}

(Received 10 May 2018; accepted 16 July 2018)

\begin{abstract}
The EU faces one of the deepest crises since its formation. A dangerous rule of law backsliding in several Member States undermines the Union's common values and puts Europe to the test. This raises the question of how to substantially address violations of EU values in judicial proceedings before the Court of Justice. Unfortunately, relying on fundamental freedoms, EU secondary legislation and even the Charter will not help much to resolve this value crisis. This Article takes a different path and calls for engaging with Article 2 TEU itself. Yet this proposal rests on a crucial premise: The judicial applicability of the values enshrined in Article 2 TEU. Based on recent jurisprudential developments, this Article will elaborate a framework for the operationalization of Article 2 TEU values and demonstrate how their judicial applicability can be construed. The judgments of Associação Sindical dos Juízes Portugueses, Minister for Justice and Equality ("L.M.") and Commission v. Poland will be at the heart of this proposal.
\end{abstract}

Keywords: Article 2 TEU; EU values; scope of EU law; Reverse Solange; Horizontal Solange

\section{A. Introduction: A Fundamental Shift Within the EU}

The Union's common values - fundamental rights, democracy, and rule of law-are under severe pressure. The developments in several EU Member States have consolidated to a larger illiberal turn, posing a systemic threat to the Union's very foundations. Especially in the new Member States, a so-called rule of law backsliding can be observed. ${ }^{1}$ Governing political parties in Poland, Hungary, and Romania started rejecting the model of a liberal democracy ${ }^{2}$ and attacking

${ }^{\star} \mathrm{PhD}$ candidate and Research Fellow at the Max Planck Institute for Comparative Public Law and International Law in Heidelberg. I am grateful to the Dienstagsrunde, especially Armin von Bogdandy, Iris Canor, Pedro Crúz Villalon, Michael Ioannidis, Christoph Krenn, and Eva Neumann as well as Lukas Huthmann, Nicole Lazzerini, Andreas Orator, Anca Mihaela Rusu, Marie-Sophie Schäfer, and Pál Sonnevend for their comments, reactions, and inspirations on this Article and earlier drafts. Section D. draws in parts on Armin von Bogdandy \& Luke D. Spieker, Countering the Judicial Silencing of Critics: Article 2 TEU Values, Reverse Solange, and the Responsibilities of National Judges, 15 Eur. Const. L. REV. (2019).

${ }^{1}$ On this term, see Laurent Pech \& Kim L. Scheppele, Illiberalism Within: Rule of Law Backsliding in the EU, 19 CAMBRIDGE Y.B. EUR. LEG. STUD. 3 (2017).

${ }^{2}$ See e.g. Viktor Orbán, Speech at the 29th Bálványos Summer Open University (July 28, 2018), www.kormany.hu/en/theprime-minister/the-prime-minister-s-speeches/prime-minister-viktor-orban-s-speech-at-the-29th-balvanyos-summer-openuniversity-and-student-camp.

(C) The Author(s) 2019. Published by Cambridge University Press on behalf of the German Law Journal. This is an Open Access article, distributed under the terms of the Creative Commons Attribution-NonCommercial-NoDerivatives licence (https://creativecommons.org/licenses/ by-nc-nd/4.0/), which permits non-commercial re-use, distribution, and reproduction in any medium, provided the original work is unaltered and is properly cited. The written permission of Cambridge University Press must be obtained for commercial re-use or in order to create a derivative work. 
checks and balances of the political process (e.g. independent courts, free media, or NGOs). ${ }^{3}$ Yet, other Member States are not immune to such attacks-as evidenced, for example, by the media concentration in Italy, Greece, and Spain. ${ }^{4}$

These developments led to a fundamental shift in the relationship between the EU and its Member States. Initially, the EU itself posed somewhat of a "threat" to fundamental rights, democracy, and the rule of law in the Member States. Although the early European Community ("EC") presented a legal space without proper fundamental rights control of its own acts, ${ }^{5}$ it demanded supremacy over all national law-even national fundamental rights. ${ }^{6}$ This deficit led to the German Solange saga. ${ }^{7}$ The Bundesverfassungsgericht, like several other constitutional courts, reserved to itself the right to review EC law for human rights violations (and eventually to suspend its application) until an EC fundamental rights protection has been established, which is "essentially comparable" to the standards set out in the German Constitution. ${ }^{8}$ Thus, the EU had to reinvent itself in order to take human rights into account. ${ }^{9}$ After over 40 years, the Union of today can be seen as a key actor in guaranteeing fundamental rights, democracy, and the rule of law in Europe. In parallel to this increasing protection at the EU level, an eroding constitutional protection can be observed in several Member States. In cases like Hungary, where Orbán secured a majority sufficient for constitutional amendments, ${ }^{10}$ national constitutions seem no longer apt to shield against attacks on fundamental rights, democracy, and the rule of law. ${ }^{11}$ These contrasting developments led to a fundamental shift in the relationship between the EU and its Member States. At least with regard to

\footnotetext{
${ }^{3}$ On Poland, see Venice Commission, Opinion on the Draft Act Amending the Act on the National Council of the Judiciary, on the Draft Act Amending the Act on the Supreme Court, and on the Act on the Organisation of Ordinary Courts, CDL-AD(2017)031-e (Dec. 8, 2017); European Commission, Reasoned Proposal in Accordance with Article 7(1) of the Treaty on European Union Regarding the Rule of Law in Poland, COM (2017) 835 final (Dec. 20, 2017). On Hungary, see Resolution on the Situation in Hungary, Eur. Parl. Doc. PV 216 (2017); Resolution on a Proposal Calling on the Council to Determine, Pursuant to Article 7(1) of the Treaty on European Union, the Existence of a Clear Risk of a Serious Breach by Hungary of the Values on which the Union is Founded, Eur. PARL. Doc. PV 340 (2018). On Romania, see Resolution on the Rule of Law in Romania, Eur. PARL. Doc. PV 446 (2018). For attempts of systematization, see Kim L. Scheppele, Autocratic Legalism, 85 U. CHI. L. Rev. 545 (2018); Günter Frankenberg, Authoritarian Constitutionalism, in Authoritarian Constitutionalism 1 (Helena A. García \& Günter Frankenberg eds., 2019).

${ }^{4}$ See Resolution on Media Pluralism and Media Freedom in the European Union, Eur. PARL. Doc. PV 204 (2018).

${ }^{5}$ See ECJ, Case C-1/58, Stork v. High Authority, ECLI:EU:C:1959:4, Judgment of 4 Feb. 1959.

${ }^{6}$ See ECJ, Case C-11/70, Internationale Handelsgesellschaft, ECLI:EU:C:1970:114, Judgment of 17 Dec. 1970.

${ }^{7}$ See Bundesverfassungsgericht (BVerfG) [Federal Constitutional Court], 2 BvL 52/71, Solange I, Judgment of 29 May 1974 , para. 62; 2 BvR 197/83, Solange II, Judgment of 22 Oct. 1986, para. 132. See also the parallel reactions of the Corte Costituzionale [Italian Constitutional Court], No. 183/73, Frontini, Judgment of 27 Dec. 1973; No. 170/1984, Granital, Judgment of 8 June 1984; No. 232/1989, Fragd, Judgment of 21 Apr. 1989.

${ }^{8}$ See BVerfG, 2 BvL 1/97, Bananenmarkt, Judgment of 7 June 2000, para. 57.

${ }^{9}$ On this prevalent narrative, see Joseph H.H. Weiler, Deciphering the Political and Legal DNA of European Integration, in Philosophical Foundations of European Union Law 137 (Julie Dickson \& Pavlos Eleftheriadis eds., 2012). Critically, Giacomo Delledonne \& Federico Fabbrini, The Founding Myth of European Human Rights Law, 44 EUR. L. REV. 178 (2019).

${ }^{10}$ On the tension between democratic mandate and rule of law dismantling, see Joseph H.H. Weiler, Epilogue: Living in a Glass House, in Reinforcing Rule of LAW Oversight In The European Union 313 (Carlos Closa \& Dimitry Kochenov eds., 2016); Martin Mendelski, Das europäische Evaluierungsdezifit der Rechtsstaatlichkeit, 44 LEVIATHAN 366, 390 (2016).

${ }^{11}$ On the questionable use of constitutional amendments to circumvent constitutional review in Hungary, see YANIV Roznai, Unconstitutional Constitutional Amendments 199 (2017); Pál Sonnevend et al., The Constitution as an Instrument of Everyday Party Politics, in Constitutional Crisis IN THE European Constitutional Area 33 (Armin von Bogdandy \& Pál Sonnevend eds., 2015).
} 
backsliding Member States, the initial Solange relationship seems to have diametrically changed: It is de facto reversed.

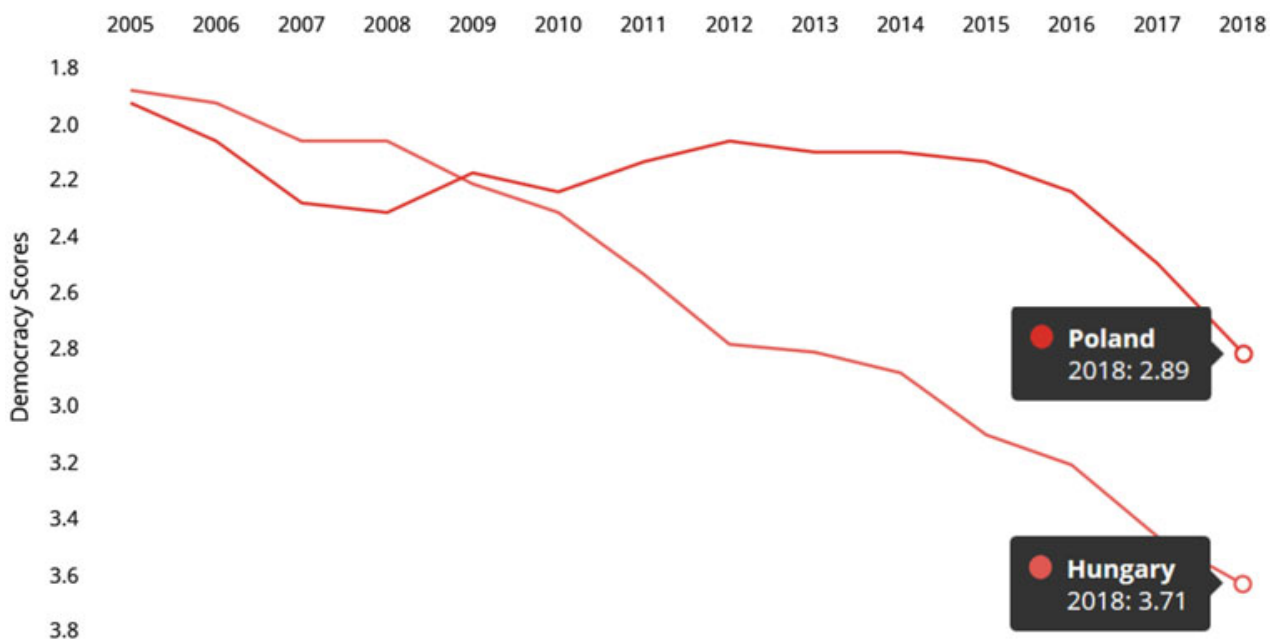

Figure 1: Democracy scores in Hungary and Poland after accession ${ }^{12}$

This reconfiguration strongly suggests that the EU should intervene in order to protect the Union's common values in the Member States. ${ }^{13}$ The question is, however, whether the EU has the capacity to act.

On their quest for European responses, most scholars concentrated on how to institutionally address these issues: ${ }^{14}$ Which institution has the mandate to proceed against backsliding Member States - the European Commission, the Council, the Court of Justice of the European Union ("CJEU"), a newly founded Copenhagen Commission, the Member States bilaterally, or eventually only the Council of Europe? Which procedures should be used-Article 7 of the Treaty on European Union ("TEU”), soft law instruments like the Commission's Rule of Law Framework, or infringement procedures before the CJEU? Still, any path requiring unanimity in the Council (Article 7 TEU) or a Treaty change ${ }^{15}$ seems to be a political pipe dream. Since

\footnotetext{
${ }^{12}$ Freedom House, NAtion In Transit (2018), freedomhouse.org/report/nations-transit/nations-transit-2018.

${ }^{13}$ On the EU's legitimacy and mandate to act, see Armin von Bogdandy, Tyrannei der Werte? Herausforderungen und Grundlagen einer europäischen Dogmatik systemischer Defizite, 79 ZAÖRV 503, 508-516 (2019); Anastasia IliopoulouPenot, La justification de l'intervention de l'Union pour la garantie de l'Etat de droit au sein des pays membres, 24 REVUE Des Affaires Européennes 7 (2019); Christophe Hillion, Overseeing the Rule of Law in the EU: Legal Mandate and Means, in ReInforcing Rule of Law Oversight, supra note 10, 59, 60-64; Carlos Closa, Reinforcing EU Monitoring of the Rule of Law, in REINFORCING RULE OF LAW OvERSIGHT, supra note 10, 15. Critically with regard to the Union's own justice and democratic deficit, see, among many others, Weiler, supra note 10.

${ }^{14}$ See e.g. Gregor Schusterschitz, The EU and Rule of Law-The Unavoidable Question of: Who Controls it?, in STRENGTHENING THE RULE OF LAW IN EuROPE 243 (Werner Schroeder ed., 2016). For comprehensive accounts, see the individual contributions to The Enforcement of Eu LaW and Values (András Jakab \& Dimitry Kochenov eds., 2017) and ReInforcing Rule of LAw Oversight, supra note 10. See also Laurent Pech et al., An EU Mechanism on Democracy, the Rule of Law and Fundamental Rights, European Parliament, Eprs (2016); Michel Waelbroeck \& Peter Oliver, La Crise de l'État de Droit dans l'Union Européenne: Que Faire?, 26 CAHIERS DE Droit Européen 299 (2017); VAssilios Skouris, Demokratie und Rechtsstaat (2018); Christoph Möllers \& Linda Schneider, Demokratiesicherung in DER EUROPÄISCHEN UNION (2018).

${ }^{15}$ See e.g. the Copenhagen Commission proposed by Jan-Werner Müller, Should the EU Protect Democracy and the Rule of Law inside Member States?, 21 EUR. L.J. 141 (2015). For an amendment of Art. 7 TEU or 51(1) CFR, see Viviane Reding, The EU and the Rule of Law - What Next? (Sept. 4, 2013), europa.eu/rapid/press-release_SPEECH-13-677_en.htm.
} 
Poland and Hungary are watching each other's backs, the Council finds itself in a deadlock situation. ${ }^{16}$

This political petrification reminds a well-known pattern of European integration: In times when the necessary actions were not pursued in the realm of politics, the CJEU stepped in as an "engine of integration" to safeguard the core of the European integration agenda. ${ }^{17}$ In the late 1960s, it was the Court that compensated the political stagnation with its constitutionalizing jurisprudence. ${ }^{18}$ In the face of a growing legitimacy deficit on the Community level, it was the Court that developed fundamental rights as general principles. ${ }^{19}$ And when facing the political inertia in constructing the internal market, it was the Court that stepped in with its doctrine of mutual recognition in Cassis de Dijon. ${ }^{20}$ When it comes to countering the illiberal turn in several Member States, a similar inertia seems to beset the political plane, and especially the Council, as the key decision maker under the Article 7 TEU procedure. Therefore, many argued to concentrate on judicial mechanisms, to employ the infringement procedure under Article 258 of the Treaty on the Functioning of the European Union ("TFEU") ${ }^{21}$ or to interact with brave national courts via the preliminary reference procedure (Article $267 \mathrm{TFEU}$ ) ${ }^{22}$ Indeed, there are good arguments in favor of relying on the CJEU. As some observed in the context of the Euro crisis, procedures before the Court have the potential to depoliticize conflicts and unfold an inclusive potential. ${ }^{23}$ Although it is true that its involvement will place an immense burden on the Court's legitimacy ${ }^{24}$ and might lead to a blame game in the affected Member States, ${ }^{25}$ it is equally true that the CJEU enjoys considerable trust from both national courts and the public. ${ }^{26}$

\footnotetext{
${ }^{16}$ See e.g. Viktor Orbán, Prime Minister, Hungary, Speech at the 28th Bálványos Summer Open University (July 22, 2017) www.kormany.hu/en/the-prime-minister/the-prime-minister-s-speeches/viktor-orban-s-speech-at-the-28th-balvanyos-summeropen-university-and-student-camp ("we must make it perfectly clear that a campaign of inquisition against Poland will never succeed, because Hungary will resort to all the legal mechanisms offered by the European Union in order to show its solidarity with the Polish people").

${ }^{17}$ Koen Lenaerts, Some Thoughts About the Interaction Between Judges and Politicians in the European Community, 12 Y.B. Eur. L. 1, 2, 10 (1992). See also Pierre Pescatore, The LAw of InTEgration 89 (1974); Robert LeCOURT, L'Europe des Juges 306-07 (1976); Renaud Dehousse, The European Court of Justice: The Politics of Judicial InTegration 70 (1998); critically, Hjalte Rasmussen, On Law and Policy in the European Court of Justice 61 (1986).

${ }^{18}$ ECJ, Case C-26/62, van Gend \& Loos, ECLI:EU:C:1963:1, Judgment of 5 Feb. 1963; Case C-6/64, Costa/ENEL, ECLI:EU:C:1964:66, Judgment of 15 July 1964; G. Federico Mancini, The Making of a Constitution for Europe, 26 Common MkT. L. Rev. 595, 612 (1989); Joseph H.H. Weiler, The Transformation of Europe, 100 YALE L.J. 2403,2425 (1991).

${ }^{19}$ See e.g. Internationale Handelsgesellschaft, Case C-11/70 at para. 4; G. Federico Mancini, Safeguarding Human Rights: The Role of the European Court of Justice, in Democracy and Constitutionalism In the European Union 81 (G. Federico Mancini ed., 2000).

${ }^{20}$ ECJ, Case C-120/78, Rewe-Zentral, ECLI:EU:C:1979:42, Judgment of 20 Feb. 1979; Pierre Pescatore, La carence du législateur communautaire et le devoir du juge (1983), in ÉTUDES DE DROIT COMMUNAUTAIRE EUROPÉEN 1962-2007 613 (Fabrice Picod ed., 2008); Kalypso Nicolaïdis, The Cassis Legacy, in Eu LAW STORIEs 278 (Fernanda Nicola \& Bill Davies eds., 2017).

${ }^{21}$ See e.g. Kim L. Scheppele, Enforcing the Basic Principles of EU Law through Systemic Infringement Actions, REINFORCING Rule of Law Oversight, supra note 10, 105. See also Matthias Schmidt \& Piotr Bogdanowicz, The Infringement Procedure in the Rule of Law Crisis, 55 Common MKT. L. Rev. 1061, 1073-80 (2018).

${ }^{22}$ See e.g. Michael Blauberger \& R. Daniel Kelemen, Can Courts Rescue National Democracy?, 24 J. Eur. PUB. POL'y 321, 325-26 (2017). See already Armin von Bogdandy et al., Reverse Solange-Protecting the Essence of Fundamental Rights, 49 COMMON MKT. L. ReV. 489 (2012).

${ }^{23}$ See Christoph Krenn \& Anuscheh Farahat, Der Europäische Gerichtshof in der Eurokrise: eine konflikttheoretische Perspektive, 57 Der StaAt 357 (2018). For a more limited influence of the Court, see Ulrich Everling, Justizielle Krisenbewältigung, in VERFASSUNGSZUSTAND UND VERFASSUNGSENTWICKLUNG DER EUROPÄISCHEN UNION 86 (Armin Hatje ed., 2015).

${ }^{24}$ See Möllers \& Schneider, supra note 14, at 107, 147; Blauberger \& Kelemen, supra note 22, at 331.

${ }^{25}$ Bernd Schlipphak \& Oliver Treib, Playing the Blame Game on Brussels, 24 J. EuR. PuB. Pol'y 352 (2017).

${ }^{26}$ In 2012, the CJEU was "the only European institution that is trusted by a majority". See EUROPEAN COMMISSION, StANDARD Eurobarometer 78, 73 (Autumn 2012) (after 2012, the Eurobarometer no longer includes data specifically on trust in the CJEU). See also R. Daniel Kelemen, The Political Foundations of Judicial Independence in the European Union, 19 J. Eur. Pub. Pol'y 43, 45, 47 (2012). On the trust of national judges in the CJEU, see Juan A. Mayoral, In the CJEU Judges Trust, 55 J. COMmon Mкт. Stud. 551 (2016).
} 
So far, jurisprudential solutions seem to prove successful as the Polish example demonstrates. Many Polish courts submitted references concerning the Polish reforms curtailing the judiciary. ${ }^{27}$ Further, the Commission decided to launch several infringement procedures. ${ }^{28}$ After interim measures were ordered by the Court, ${ }^{29}$ the Polish government immediately reversed some parts of its reforms. ${ }^{30}$ This shows that governments in backsliding Member States remain responsive to the CJEU's decisions.

This leads to the following question, which will be at the heart of this Article: What happens when a case, in which Union values are at stake, reaches the CJEU? The crucial problem is that important parts of the Polish or Hungarian reforms do not seem to be related to any EU law. So which substantive provisions can be invoked in a procedure before the CJEU? In the following, this Article will briefly expose why relying on fundamental freedoms, secondary legislation, or the Charter is not sufficient to cover threats to Union values in the Member States (B.). It will then analyze two approaches aiming at tackling the identified insufficiencies-the initial Reverse Solange and the Horizontal Solange doctrine. Although both concepts establish ways to protect the Union's common values in situations that seem to escape the scope of EU law, they present some significant shortcomings and cannot cover illiberal developments in the Member States in all their facets (C.). Therefore, this Article argues for a more comprehensive approach: Relying on Article 2 TEU itself. Yet, this path rests on a central premise: The judicial applicability of the values enshrined in Article 2 TEU. Based on recent jurisprudential developments and the CJEU's stance in the procedures against Poland, this Article will elaborate a framework for the operationalization of Article 2 TEU values and their judicial applicability (D.). The judgments of Associação Sindical dos Juízes Portugueses (“ASJP"), ${ }^{31}$ Minister for Justice and Equality ("L.M."), ${ }^{32}$ and Commission v. Poland $^{33}$ will be at the heart of this proposal.

\section{B. The Limited Scope of Fundamental Freedoms, Secondary Legislation, and the Charter}

A first approach to addressing illiberal developments in the Member States under EU law is to rely upon provisions of the established EU acquis, which are not specifically designed or targeted at preserving fundamental rights, democracy, and the rule of law-like fundamental freedoms or

\footnotetext{
${ }^{27}$ On the Polish retirement ages for judges, see the references in Zakład Ubezpieczeń Społecznych (C-522/18); Unipart (C-668/18); on the new Polish disciplinary chamber and the influence of the President of Republic and the Minister of Justice on its composition, see A.K. (Indépendance de la chambre disciplinaire de la Cour suprême) (C-585/18, C-624/18 \& C-625/18), and the references in cases C-537/18 and C-824/18; on the disciplinary measures against ordinary judges, see Miasto Łowicz (C-558/18 \& C-563/18) and Prokuratura Rejonowa w Stubicach (C-623/18). See also the references submitted in Prokurator Generalny (C-508/19) and W.Ż. (C-487/19). See further the preliminary reference by the Pest Central District Court, pending as IS (C-564/19).

${ }^{28}$ See ECJ, Case C-619/18 R, Commission v. Poland (Indépendance de la Cour suprême), ECLI:EU:C:2019:531, Judgment of 24 June 2019; Case C-192/18, Commission v. Poland (Indépendance des juridictions de droit commun), ECLI:EU:C:2019:924, Judgment of 5 Nov. 2019. Another procedure has been initiated against the disciplinary regime for judges, see European Commission, Rule of Law: European Commission launches infringement procedure to protect judges in Poland from political control (Apr. 3., 2019), europa.eu/rapid/press-release_IP-19-1957_en.htm. Further, proceedings against Hungary for its Foreign NGO and Higher Education laws are pending before the CJEU under Commission v. Hungary (Enseignement supérieur) (C-66/18) and Commission v. Hungary (Transparence associative) (C-66/18).

${ }^{29} \mathrm{See}$ the orders of October 19 and December 2017, 2018 in Commission v. Poland, Case C-619/18.

${ }^{30}$ On November 21, 2018 the Polish Sejm passed an act reinstating the previous retirement age for judges, see Press Release, President Signs Bill Amending Law on Supreme Court (Dec. 17, 2018), www.president.pl/en/news/art,926,president-signsbill-amending-law-on-supreme-court.html.

${ }^{31}$ ECJ, Case C-64/16, Associação Sindical dos Juízes Portugueses, ECLI:EU:C:2018:117, Judgment of 27 Feb. 2018.

${ }^{32}$ ECJ, Case C-216/18 PPU, Minister for Justice and Equality, ECLI:EU:C:2018:586, Judgment of 25 July 2018.

${ }^{33}$ Commission v. Poland, Case C-619/18.
} 
secondary legislation from the internal market context. At first sight, this "get Al Capone on tax evasion strategy" 34 seems to be a clever and reliable move because it arguably depoliticizes the case and avoids the uncertainties attached to new and untested legal concepts. Yet these instruments are too limited to address the developments in backsliding Member States.

The application of fundamental freedoms usually requires a cross-border element. Therefore, many Member State areas do not come within their scope. Although cross-border requirements have lost some of their significance in the CJEU's jurisprudence, ${ }^{35}$ the fact remains that it will be extremely difficult (if not impossible) to always find a link to fundamental freedoms when Union values are at stake. ${ }^{36}$ Fundamental freedoms are-except for the free movement of persons-embedded in the internal market context and its economic rationales. Although this does not exclude taking fundamental rights, democracy, or rule of law considerations into account, these considerations remain complementary. As such, it seems difficult to image how one could address for example attacks on judicial independence under these instruments.

Relying on secondary legislation is of rather limited utility as well. Experience shows that such an approach leads to superficial, eventually unsuccessful, results. The infringement procedures against the judicial reforms in Hungary (reduction of retirement ages for judges) can serve as an illustrating example. ${ }^{37}$ The Commission based the procedures on non-compliance with Directive 2000/78 on age discrimination. Although the case was a legal success, its practical implications were limited. Instead of reinstating the judges, the government offered them compensation, a reasonable remedy in discrimination cases. It was therefore no surprise that the Hungarian government was able to avoid restoring many judges to their prior position while still complying with the CJEU's verdict. ${ }^{38}$

Finally, the scope of the Charter of Fundamental Rights of the European Union ("CFR") is subject to a double restriction ratione materiae: First, it does not cover threats of structural or institutional nature detached from individual rights violations. Without a doubt, human rights, democracy, and the rule of law are essentially interrelated or co-constitutive. ${ }^{39}$ Their relationship has been incisively compared to the legs of a three-legged stool: "If one is missing the whole is not fit for purpose". ${ }^{40}$ Yet they are not identical, because democracy and the rule of law also include elements that affect the organization of State-for example, the separation of powers. In this sense, dangers to democracy and the rule of law are not always depictable as fundamental rights violations. This division into separate but interrelated dimensions seems to derive from the EU framework itself. Article 2 TEU differentiates between "democracy, ... the rule of law and respect for human rights". This corresponds with the findings of the EU Agency for Fundamental Rights ("FRA"), which conducted an extensive study on the equivalence of Article 2 values and human rights enshrined in the Charter. According to this study, not every value has a fundamental rights counterpart. Both value-dimensions - institutional/structural and fundamental rights - are only

\footnotetext{
${ }^{34}$ Blauberger \& Kelemen, supra note 22, at 325-26.

${ }^{35}$ See e.g. Sara Iglesias Sánchez, Purely Internal Situations and the Limits of EU Law: A Consolidated Case Law or a Notion to be Abandoned?, 14 Eur. Const. L. REv. 7 (2018).

${ }^{36}$ For such attempts, see the grounds on which the Commission brought its infringement proceedings against Hungary (supra note 28). For a further discussion of this path, see Mark Dawson \& Elise Muir, Hungary and the Indirect Protection of EU Fundamental Rights and the Rule of Law, 14 GERMAN L.J. 1959 (2013).

${ }^{37} \mathrm{See}$ ECJ, Case C-286/12, Commission v. Hungary, ECLI:EU:C:2012:687, Judgment of 6 Nov. 2012.

${ }^{38}$ For a comprehensive account, see Gábor Halmai, The Case of the Retirement Age of Hungarian Judges, in EU LAW STORIES, supra note 20, at 471 (2017).

${ }^{39}$ JÜrgen Habermas, The Inclusion of the Other 253 (2005). See also Venice Commission, Report on the Rule of Law, CDL-AD (2011) 003rev (Apr. 4, 2011).

${ }^{40}$ Sergio Carrera et al., The Triangular Relationship between Fundamental Rights, Democracy and the Rule of Law in the EU, European Parliament, Libe (2013), at 30.
} 
partially overlapping. Especially democracy and the rule of law are not covered in their entirety by the Charter:

\begin{tabular}{ll}
\hline Values listed in Art. 2 TEU & $\begin{array}{l}\text { Equivalence in the CFR (shaded titles cover the } \\
\text { corresponding Art. 2 values only partly) }\end{array}$ \\
\hline Human dignity & Human dignity (Title I) \\
Freedom & Freedoms (Title II) \\
Democracy & Citizen's rights (Title V) \\
Equality & Equality (Title III) \\
Rule of law & Justice (Title VI), Citizen's rights (Title V) \\
Respect for human rights & All titles of the CFR \\
Rights of the persons belonging to minorities & Equality (Title III) \\
Pluralism & Equality (Title III) \\
Non-discrimination & Equality (Title III) \\
Tolerance & Equality (Title III) \\
Justice & Justice (Title VI) \\
Solidarity & Solidarity (Title IV) \\
Equality between women and men & Equality (Title III) \\
\hline
\end{tabular}

Figure 2: Comparison between Article 2 TEU values and the CFR rights ${ }^{41}$

Second, even if one succeeds in addressing illiberal developments in the Member States as fundamental rights issues, such an approach would have to fall within the Charter's scope of application. Pursuant to Article 51(1) CFR, the Charter is only applicable to Member State actions "when they are implementing Union law". In using this formula, Article 51(1) meant to cover the jurisprudential status quo before the Charter's entry into force. ${ }^{42}$ According to the Court's case law, EU fundamental rights (at that time general principles) were only binding on the Member States when they were acting within the "scope of Community law" 43 - meaning when a Member State implemented EU law (e.g. a directive or regulation, so-called agency-situation ${ }^{44}$ ) or when it made use of the derogations or justifications permitted by EU law (derogationsituation). ${ }^{45}$

In Akerberg Fransson, the Court made clear that the Charter does not change the preceding case law and reiterated the formula that EU fundamental rights apply to Member State actions only in "situations ... within the scope of European Union law". ${ }^{46}$ As Koen Lenaerts put it: "Just as an object defines the contours of its shadow, the scope of EU law determines that of the Charter." ${ }^{\prime 7}$ This limitation is based on a narrow understanding of the Charter's aim and purpose

\footnotetext{
${ }^{41}$ FRA, Fundamental Rights-Annual Report 2013 (2014), at 10.

${ }^{42}$ See Explanations Relating to the Charter of Fundamental Rights, 2007 O.J. (C 303/02) 17, at 32.

${ }^{43}$ See e.g. ECJ, Case C-309/96, Annibaldi, ECLI:EU:C:1997:631, Judgment of 18 Dec. 1997, para. 13; Joined Cases 60 \& 61/84, Cinéthèque, ECLI:EU:C:1985:329, Judgment of 11 July 1985, para. 25.

${ }^{44}$ ECJ, Case C-5/88, Wachauf, ECLI:EU:C:1989:321, Judgment of 13 July 1989, para. 19.

${ }^{45}$ ECJ, Case C-260/89, ERT, ECLI:EU:C:1991:254, Judgment of 18 June 1991, para. 43.

${ }^{46}$ ECJ, Case C-617/10, Åkerberg Fransson, ECLI:EU:C:2013:105, Judgment of 26 Feb. 2013, paras. 18-19. For attempts to systematize the meandering post-Fransson case law, see Nicole LAZZERIni, La CARTa Dei DiritTi Fondamentali DELl'Unione Europea. I Limiti di Applicazione 183 et seq. (2018); Eleanor Spaventa, The Interpretation of Article 51 of the EU Charter of Fundamental Rights, European Parliament, Peti (2016); Marek Safjan, Dominik Düsterhaus \& Antoine Guérin, La Charte des droits fondamentaux de l'Union européenne et les ordres juridiques nationaux, REVUE Trimestrielle de Droit Européen, 219 (2016); Michael Dougan, Judicial Review of Member State Action under the General Principles and the Charter, 52 Common MKT. L. REv. 1201 (2015); Filippo Fontanelli, The Implementation of European Union Law by Member States under Article 51(1) of the Charter, 20 Colum. J. EuR. L. 193 (2014); Sarmiento, Who's Afraid of the Charter?, 50 Common MKT. L. REv. 1267, 1303 (2013).

${ }^{47}$ Koen Lenaerts \& José A. Gutiérez-Fons, The Place of the Charter in the EU Constitutional Edifice, in THE EU CHARTER OF Fundamental Rights: A Commentary 1559, 1567 (Steve Peers et al. eds., 2014).
} 
with regard to the Member States. When the Charter was introduced, the Member States already had mechanisms for the protection of fundamental rights in place. Yet, diverging fundamental rights standards applying to the Member States' implementation of EU law were perceived as a threat to its coherent and uniform application. For the Court, the Charter's central aim vis-à-vis the Member States is therefore "to avoid a situation in which the level of protection of fundamental rights varies ... in such a way as to undermine the unity, primacy and effectiveness of EU law". ${ }^{48}$ The Charter is just an accessory of EU law-a vehicle to secure its uniform application. In this sense, EU fundamental rights cannot go beyond what is necessary to perform this function. ${ }^{49}$ This excludes purely internal situations, fields where the EU has potential powers which have not actually been exercised ${ }^{50}$ and purely hypothetical links. ${ }^{51}$

This double limitation makes it difficult to address illiberal developments in the Member States. Since important parts of the respective reforms do not seem to be covered by Union law or are of a structural nature, the Charter is not the right tool to address these issues. So, what can be done?

\section{Tackling the Identified Insufficiencies: Multiplying Solange?}

A new, multiplied Solange approach could remedy this situation. The following section will outline and discuss two ideas of how Solange strategies could tackle the identified insufficiencies and protect the Union's common values even in situations that seem to escape the scope of EU law. While Reverse Solange is a doctrinal proposal, the Horizontal Solange approach is already practiced jurisprudence.

\section{The Initial Reverse Solange Doctrine}

Reverse Solange goes back to Armin von Bogdandy and his team who proposed to link EU fundamental rights to EU citizenship. In Ruiz Zambrano, the CJEU held that Article 20 TFEU, the provision establishing EU citizenship, "precludes national measures which have the effect of depriving citizens of the Union of ... the substance of the rights conferred by virtue of their status as citizens of the Union", ${ }^{52}$ irrespective of whether it is a purely internal situation. ${ }^{53}$ Accordingly, a Union citizen can challenge any Member State act before a national court on the grounds that the "substance" of its Union citizenship is violated. The Heidelberg group proposed that EU

\footnotetext{
${ }^{48}$ ECJ, Case C-206/13, Siragusa, ECLI:EU:C:2014:126, Judgment of 6 March 2014, para. 32; Case C-399/11, Melloni, ECLI: EU:C:2013:107, Judgment of 16 Feb. 2013, para. 60; Case 44/79, Hauer, ECLI:EU:C:1979:290, Judgment 13 Dec. 1979 , para. 14. For the locus classicus of this critique, see Jason Coppel \& Aidan O'Neill, The European Court of Justice: Taking Rights Seriously?, 29 COMMON MKT. L. Rev. 669, 670 (1992).

${ }^{49} \mathrm{On}$ the requirement for a specific provision of EU law actually applying in the case at hand, see e.g. Angela Schwerdtfeger, Art. 51-Anwendungsbereich, in Charta Der Grundrechte Der EuropäIschen Union paras. 46, 51 (Jürgen Meyer \& Sven Hölscheidt eds., $5^{\text {th }}$ ed. 2019); Safjan, Düsterhaus \& Guérin, supra note 46, at 223; Marek Safjan, Fields of Application of the Charter of Fundamental Rights and Constitutional Dialogues in the European Union, EUI DISTINGUISHED LECTURE 2014/02, at 4; Sarmiento, supra note 46, at 1279; Clemens Ladenburger, European Union Institutional Report, in PROTECTION OF Fundamental Rights Post-Lisbon 141, 163 (Julia Laffranque ed., 2012); Allan Rosas, When is the EU Charter of Fundamental Rights Applicable at National Level?, 19 JURISPRUDENCE 1269, 1284 (2012).

${ }^{50}$ On such a proposal, see Opinion of Advocate General Sharpston, Case C-34/09, Ruiz Zambrano (Sept. 30, 2010); rejecting this line of reasoning, see ECJ, Case C-370/12, Pringle, ECLI:EU:C:2012:756, Judgment of 27 Nov. 2012, paras. 180-181; Case C-198/13, Hernández, ECLI:EU:C:2014:2055, Judgment of 10 July 2014, para. 36.

${ }^{51}$ See ECJ, Case C-299/95, Kremzow, ECLI:EU:C:1997:254, Judgment of 19 May 1997, para. 16; Case C-40/11, Iida, ECLI: EU:C:2012:691, Judgment of 8 Nov. 2012, para. 77.

${ }^{52}$ ECJ, Case C-34/09, Ruiz Zambrano, ECLI:EU:C:2011:124, Judgment of 8 Mar. 2011, para. 42.

${ }^{53} \mathrm{See}$ Koen Lenaerts, 'Civis europaeus sum': From the Cross-border Link to the Status of Citizen of the Union, in Constitutionalising The Eu Judicial System 213 (Pascal Cardonnel et al. eds., 2012); Peter Van Elsuwege, European Union Citizenship and the Purely Internal Rule Revisited, 7 Eur. Const. L. Rev. 308, 323 (2011); Daniel Dittert, Les droits des citoyens de l'Union vers un statut détaché de tout élément transfrontalier?, 18 REVUE DES AFFAIRES EUROPÉENNES 223 (2011).
} 
fundamental rights should form part of this substance. ${ }^{54}$ To link human rights with citizenship and to shift from the current ratione materiae approach under Article 51(1) CFR to an approach ratione personae is not entirely new. ${ }^{55}$ What is new is to exercise this power in form of a reverse Solange presumption. Beyond the scope of Article 51(1), Member States remain autonomous with respect to fundamental rights as long as it can be presumed that they secure the essence of EU fundamental rights protected under Article 2 TEU. Only in case of a systemic violation, this presumption is rebutted, and individuals may rely on their status as Union citizens to seek redress before national courts, which could (and should) refer the matter to the CJEU.

Obviously, this proposal was subject to criticism. ${ }^{56}$ Since the essence of EU fundamental rights would apply even in purely internal situations, the doctrine was perceived as being incompatible with Article 51(1) CFR. Yet, one could argue that it is EU citizenship that changes the scope of application of EU law in the first place. If EU citizens can rely on the substance of their citizenship in purely internal situations, then it is not a purely internal situation anymore-it is drawn within the scope of EU law. As such, Union citizenship paves the way for the application of the Charter and EU fundamental rights remain accessory to the Treaties ${ }^{57}$ Further, Reverse Solange is subject to a double limitation: It operates in form of a presumption and does not rely on the full EU fundamental rights acquis, but only on its essence. ${ }^{58}$ Therefore, Article 51(1) cannot be seen as circumvented-it still restricts the scope of the full EU fundamental rights acquis.

Despite the skillfully anticipated critique, ${ }^{59}$ the initial Reverse Solange doctrine suffers from three major shortcomings: ${ }^{60}$ First, its jurisprudential hook-the judgment in Ruiz Zambrano-does not reflect the current jurisprudential outlook anymore. In the early 2000s, there was a trend towards strengthening the normative status of Union citizenship culminating eventually in Ruiz Zambrano. ${ }^{61}$ In this spirit, some commentators already anticipated a "federal turn". ${ }^{62}$ Since 2012, however, the jurisprudential landscape has radically changed:

\footnotetext{
${ }^{54}$ See von Bogdandy et al., supra note 22, at 508.

${ }^{55}$ See Opinion of Advocate General Jacobs at para. 46, Case C-168/91, Konstantinidis (Dec. 9, 1992) and Opinion of Attorney General Maduro at paras. 16-21, Case C-380/05, Centro Europa 7 (Sept. 12, 2007). See also Siofra O’Leary, The Relation Between Community Citizenship and the Protection of Fundamental Rights in Community Law, 32 CommoN MкT. L. Rev. 519 (1995); Peter Neussl, European Citizenship and Human Rights, 24 Leg. Iss. ECON. INTEG. 47 (1997).

${ }^{56}$ See Koen Lenaerts \& José A. Gutiérrez-Fons, Epilogue on EU Citizenship: Hopes and Fears?, in EU CITIZENSHIP AND Federalism 751, 771 et seq. (Dimitry Kochenov ed., 2017). See also Koen Lenaerts, EU Citizenship and Democracy, 7 New J. Eur. Crim. L. 164, 171 (2016); Id., Linking EU Citizenship to Democracy, 11 Croatian Y.B. Eur. L. \& Pol'y VII, XVI (2015); Dimitry Kochenov, On Policing Article 2 TEU Compliance, 33 Polish Y.B. INT'L L. 145, 165 (2013); Johanna Croon-Gestefeld, Reverse Solange: Union Citizenship as a Detour on the Route to European Rights Protection against National Infringements, in EU CITIZENSHIP AND FEDERALISM, supra, 665.

${ }^{57}$ See Martijn van den Brink, EU Citizenship and EU Fundamental Rights, 39 LEG. Iss. ECON. INTEG. 273, 283 (2012).

${ }^{58}$ von Bogdandy et al., supra note 22, at 515.

${ }^{59} \mathrm{Id}$. at $514-518$.

${ }^{60}$ For a "repositioned" version of Reverse Solange, see Armin von Bogdandy \& Luke D. Spieker, Countering the Judicial Silencing of Critics: Article 2 TEU Values, Reverse Solange, and the Responsibilities of National Judges, 15 EUR. CONST. L. REv. (2019); Id., Protecting Fundamental Rights Beyond the Charter. Repositioning the Reverse Solange Doctrine in Light of the CJEU's Article 2 TEU Case Law, in The Eu Charter of Fundamental Rights in the Member States (Michal Bobek \& Jeremias Prassl eds., forthcoming 2020).

${ }^{61}$ On the "fundamental status" jurisprudence, see ECJ, Case C-184/99, Grzelczyk, ECLI:EU:C:2001:458, Judgment of 20 Sept. 2001, para. 31; Case C-135/08, Rottmann, ECLI:EU:C:2010:104, Judgment of 2 Mar. 2010, para. 43; extending derived protection to third country nationals, see ECJ, Case C-413/99, Baumbast, ECLI:EU:C:2002:493, Judgment 17 Sept. 2002; Case C-127/08, Metock, ECLI:EU:C:2008:449, Judgment of 25 July 2008; extending protection to economically inactive citizens, see ECJ, Case C-456/02, Trojani, ECLI:EU:C:2004:488, Judgment of 7 Sept. 2004; Case C-85/96, Martinez Sala, ECLI:EU: C:1998:217, Judgment of 12 May 1998.

${ }^{62}$ Martijn van den Brink, The Origins and the Potential Federalising Effect of the Substance of Rights Test, in EU CITIZENSHIP AND Federalism, supra note 56, 85, 104; Sara Iglesias Sánchez, Fundamental Rights and Citizenship of the Union at a Crossroads, 20 EUR. L.J. 464, 473 (2014); Luca Manigrassi, Vers une citoyenneté européenne fédérale?, REVUE DU DROIT DE L'UNION EUROPÉENNE 411 (2011).
} 
In an almost "reactionary phase", ${ }^{63}$ the Court began to construe the substance of citizens' rights ${ }^{64}$ and their right to equal treatment in increasingly restrictive terms. ${ }^{65}$ Even if the Court did not expressly shut the doors to any link between fundamental rights and citizenship in the future, it does not seem very likely that the Court will further pursue this path. ${ }^{66}$ Thus, the Zambrano-detour-essential twist for addressing purely internal situations in the Member States under the initial Reverse Solange doctrine-does not seem a viable path any more.

Second, linking fundamental rights and citizenship simultaneously excludes third country nationals. Indeed, citizenship is an inherently exclusionary concept. ${ }^{67}$ This leads to a gap between universal human rights and particularistic citizenship rights. ${ }^{68}$ It is therefore not surprising that fundamental rights have been progressively decoupled from the status of citizenship in recent years and extended equally to foreigners and third country nationals. ${ }^{69}$ This must apply in particular to Union citizenship. The whole ethos of European integration is about inclusion rather than the exclusion of the "other" ${ }^{70}$ To recall the warning words of Joseph Weiler: "We have made little progress if the Us becomes European [instead of German or French or British] and the Them becomes those outside the Community." ${ }^{71}$ As such, premising fundamental rights on citizenship could oppose the EU's very own values.

Third, and last, the initial Reverse Solange doctrine is conceptually limited to the enforcement of EU fundamental rights. It presupposes a Union citizen vindicating his or her individual rights. Consequently, this approach does not counter threats to democracy or the rule of law in their structural or institutional dimension. ${ }^{72}$ As such, Reverse Solange is an important but nonetheless limited tool.

\section{The Horizontal Solange Doctrine}

A less straightforward way to assess and enforce democracy, rule of law, and fundamental rights compliance in the Member States in situations, which seem to escape the scope of EU law, could be the use of what has been termed a Horizontal Solange approach. ${ }^{73}$ The point of departure for this approach are mutual recognition regimes in the area of EU cooperation in civil and criminal

\footnotetext{
${ }^{63}$ Eleanor Spaventa, Earned Citizenship, in Eu Citizenship AND Federalism, supra note 56, 204, 205.

${ }^{64}$ See ECJ, Case C-256/11, Dereci, ECLI:EU:C:2011:734, Judgment of 15 Nov. 2011, para. 64; Case C-434/09, McCarthy, ECLI:EU:C:2011:277, Judgment of 5 May 2011; Case C-87/12, Ymeraga, ECLI:EU:C:2013291, Judgment of 8 May 2013 , para. 37; Iida, Case C-40/11 at para. 72.

${ }^{65}$ See ECJ, Case C-333/13, Dano, ECLI:EU:C:2014:2358, Judgment of 11 Nov. 2014; Case C-67/14, Alimanovic, ECLI:EU: C:2015:597, Judgment of 15 Sept. 2015; Case C-308/14, Commission v. United Kingdom, ECLI:EU:C:2016:436, Judgment of 14 June 2016. See also Daniel Thym, The Judicial Deconstruction of Union Citizenship, in QuesTIONING EU CITIZENSHIP 1 (Daniel Thym ed., 2017); Anastasia Iliopolou-Penot, Deconstructing the Former Edifice of Union Citizenship?, 53 ComMON MKT. L. ReV. 1007 (2016); Steve Peers, Benefits for EU Citizens: A U-Turn by the Court of Justice, 74 CAMBRIDGE L.J. 195, 196 (2015).

${ }^{66}$ For possible explanations, see Michael Blauberger et al., ECJ Judges Read the Morning Papers. Explaining the Turnaround of European Citizenship Jurisprudence, 25 J. EUR. PUB. POL'Y 1422 (2018); Urška Šadl \& Mikael R. Madsen, Did the Financial Crisis Change European Citizenship Law?, 22 Eur. L.J. 40 (2016).

${ }^{67}$ See Samantha Besson \& André Utzinger, Towards European Citizenship, 39 J. Soc. PHIL. 185, 187-88, 191 (2008). See generally Linda Bosniak, Status Non-Citizens, in The Oxford Handbook OF Citizenship 314, 320 et seq. (Ayelet Shachar et al. eds., 2017).

${ }^{68}$ Besson \& Utzinger, supra note 67, at 190; Linda Bosniak, Persons and Citizens in Constitutional Thought, 8 ICON 9 (2010).

${ }^{69}$ See e.g. Bosniak, supra note 67, at 330; Ruth Rubio-Marín, Human Rights and the Citizen/Non-Citizen Distinction Revisited, in Human Rights and Immigration 1, 12 (Ruth Rubio-Marín ed., 2014); Martijn van den Brink, EU Citizenship and (Fundamental) Rights: Empirical, Normative, and Conceptual Problems, 25 EUR. L.J. 21,28 (2019).

${ }^{70}$ See van den Brink, supra note 69, at 30.

${ }^{71}$ Joseph H.H. Weiler, Thou Shalt Not Oppress a Stranger: On the Judicial Protection of the Human Rights of Non-ECNationals, 3 Eur. J. INT'L L. 65, 68 (1992).

${ }^{72} \mathrm{On}$ the difficulties of addressing institutional rule of law or democracy concerns under the Charter, see supra Section B.

${ }^{73}$ See Iris Canor, My Brother's Keeper? Horizontal Solange, 50 Common MKT. L. ReV. 383 (2013).
} 
matters. Stemming originally from the internal market context, mutual recognition regimes are EU mechanisms facilitating cooperation between (and recognition of) autonomous Member State policies without harmonization on the EU level. Examples for this mode of integration are the European Arrest Warrant ("EAW"), ${ }^{74}$ the Common European Asylum System ("CEAS"), ${ }^{75}$ or judicial cooperation in civil matters. ${ }^{76}$ These mechanisms rely on one central premise: Mutual trust between the Member States-the confidence that every Member State complies with EU standards. $^{77}$

Take the EAW as an example: Generally, a Member State triggers its own human rights responsibility if it surrenders a person to a Member State where it would be subject to human rights violations. ${ }^{78}$ Accordingly, the surrendering State has to examine the conditions in the issuing State. This is where the principle of mutual trusts intervenes. To facilitate an automatic cooperation among Member States and allow "an area without internal borders to be created and maintained", ${ }^{79}$ the executing State can rely upon the presumption that the issuing State complies with all EU standards. However, the principle of mutual trust does not stop there: It also entails an obligation for the executing Member States to refrain from assessing whether the issuing Member State complies with EU standards. ${ }^{80}$ Thus, the grounds for refusing to execute an EAW were initially limited to the ones explicitly listed in the Framework Decision. ${ }^{81}$

\section{Mutual Recognition Regimes: Gateways for Rule of Law and Fundamental Rights Considerations}

Yet even besides these explicit grounds, national judges can make cooperation under mutual recognition regimes subject to fundamental rights and rule of law considerations. These exceptions allow to assess the situation in the issuing Member State even concerning issues, which do not seem to be covered by EU law. That is the case in two kinds of situations.

First, judges can determine whether the conditions for a request for cooperation or recognition have been validly formed in the first place-for example, under the EAW Framework, whether the arrest warrant has been issued by a "judicial authority" in the sense of Article 6(1) of the Framework Decision. According to the CJEU in Kovalkovas, the concept of "judicial authority" is an autonomous notion of EU law, referring to an entity independent from the executive. ${ }^{82}$ A similar reasoning applies to the mutual recognition of judgments. In Pula Parking, the Court

\footnotetext{
${ }^{74}$ See Council Framework Decision 2002/584/JHA on the European Arrest Warrant, 2002 O.J. (L 190) 1.

${ }^{75}$ See e.g. Regulation 604/2013 establishing the criteria and mechanisms for determining the Member State responsible for examining an application for international protection (Dublin III), 2013 O.J. (L 180) 31.

${ }^{76}$ See e.g. Regulation 593/2008 on the Law Applicable to Contractual Obligations (Rome I), 2008 O.J. (L 177) 6; Regulation $864 / 2007$ on the Law Applicable to Non-contractual Obligations (Rome II), 2007 O.J. (L 199) 40; Regulation 1215/2012 on Jurisdiction and the Recognition and Enforcement of Judgements in Civil and Commercial Matters (recast) (Brussels I bis), 2012 O.J. (L 351) 1; Council Regulation 2201/2003 concerning jurisdiction and the recognition and enforcement of judgments in matrimonial matters and the matters of parental responsibility (Brussels II bis), 2003 O.J. (L 338) 1.

${ }^{77}$ From the recent debate, see Cecilia Rizcallah, The Challenges to Trust-Based Governance in the European Union, 25 EUR. L.J. 37 (2019); Armin von Bogdandy, Ways to Frame the European Rule of Law, EuR. Const. L. ReV. 675 (2018); Koen Lenaerts, La vie après l'avis: Exploring the Principle of Mutual (Yet Not Blind) Trust, 54 Common MkT. L. Rev. 805 (2017); Frank Meyer, Der Grundsatz gegenseitigen Vertrauens, 52 EUROPARECHT 163 (2017). For a theoretical underpinning, see Michael Schwarz, Let's Talk About Trust, Baby! Theorizing Trust and Mutual Recognition in the EU's Area of Freedom, Security and Justice, 24 EUR. L.J. 124 (2018); Thomas Wischmeyer, Generating Trust Through Law? Judicial Cooperation in the European Union and the "Principle of Mutual Trust", 17 GERMAN L.J. 339 (2017); critically, Martin Nettesheim, Überdehnt der EuGH den Grundsatz gegenseitigen Vertrauens?, 20 ZEITSCHRIFT FÜR EUROPARECHT 4 (2018).

${ }^{78}$ See e.g. Soering v. United Kingdom, App. No. 14038/88 (July 7, 1929).

${ }^{79}$ ECJ, Opinion 2/13, EU Accession to the ECHR II, ECLI:EU:C:2014:2454, Opinion of 18 Dec. 2014, para. 191.

${ }^{80}$ See Minister for Justice and Equality, Case C-216/18 PPU at para. 37; EU Accession to the ECHR II, Opinion 2/13 at para. 192.

${ }^{81}$ See ECJ, Case C-237/15 PPU, Lanigan, ECLI:EU:C:2015:474, Judgment of 16 July 2015, para. 36; Case C-396/11, Radu, ECLI:EU:C:2013:39, Judgment of 29 Jan. 2013, paras. 35-36.

${ }^{82}$ ECJ, Case C-477/16 PPU, Kovalkovas, ECLI:EU:C:2016:861, Judgment of 10 Nov. 2016, para. 36. See also ECJ, Case C452/16 PPU, Poltorak, ECLI:EU:C:2016:858; Judgment of 10 Nov. 2016, para. 35; Case C-453/16 PPU, Özçelik, ECLI:EU:
} 
stated that only entities that offer guarantees of independence and impartiality could be considered as "court" within the meaning of the Brussels I bis Regulation. ${ }^{83}$ Therefore, both the EAW and EU Private International Law allow for the assessment of the issuing or rendering authority's independence and can lead eventually to a denial of cooperation.

Second, after the EAW or the respective judgment has been validly issued or rendered, national judges can determine whether they must deny cooperation due to the risk of fundamental rights violations in the issuing Member State. Realizing the potential for conflict and inconsistencies with the European Charter of Human Rights ("ECHR") and the Union's own Charter-and probably pushed by national constitutional courts ${ }^{84}$ — the CJEU began clarifying that mutual trust must not be confused with blind trust and that limitations can be made "in exceptional circumstances" ${ }^{85}$ For example, EAWs must be suspended or postponed if a surrender would amount to an inhumane and degrading treatment under Article 4 CFR. ${ }^{86}$ To trigger such a postponement, a twopronged test has to be satisfied (Aranyosi-test): First, the applicant must demonstrate systemic deficiencies amounting to a real risk of inhumane and degrading treatment. ${ }^{87}$ Second, there must be "substantial grounds to believe that the individual concerned will be exposed to that risk". 88 Similar developments can be observed under the Dublin System ${ }^{89}$ and to a lesser extent under EU Private International Law. ${ }^{90}$

These exceptions have far-reaching implications: They allow Member State courts and (in case of a reference) the CJEU to review internal Member State policies even concerning issues that seem to fall outside the scope of Union law.

First, Member State courts are empowered within the framework of mutual recognition regimes to review whether other Member States issuing EAWs or rendering judgements abide by essential European standards. Cooperation will be maintained as long as the other Member State generally adheres to these standards. Iris Canor termed this peer review Horizontal Solange. ${ }^{11}$ Second, mutual recognition regimes immensely extend the CJEU's scope of review.

C:2016:860, Judgment of 10 Nov. 2016, para. 31; Joined Cases 508/18 \& 82/19 PPU, OG (Parquet de Lübeck), ECLI:EU: C:2019:456, Judgment of 27 May 2019, para. 74.

${ }^{83}$ ECJ, Case C-551/15, Pula Parking, ECLI:EU:C:2017:193, Judgment of 9 March 2017, para. 54.

${ }^{84}$ See e.g. BVerfG, 2 BvR 2236/04, European Arrest Warrant, Judgment of 18 July 2005, para. 78 ("mutual confidence ... does not release the legislature from reacting, in cases in which such confidence ... has been profoundly shaken").

${ }^{85}$ EU Accession to the ECHR II, Opinion $2 / 13$ at paras. 191, 194; see also Lenaerts, supra note 77, at 806; Georgios Anagnostaras, Mutual Confidence is Not Blind Trust!, 53 Common Mkt. L. Rev. 1675 (2016); Auke Willems, The Court of Justice of the European Union's Mutual Trust Journey in EU Criminal Law: From a Presumption to (Room for) Rebuttal, 20 GERMAN L.J. 468 (2019).

${ }^{86}$ ECJ, Joined Cases 404 \& 659/15 PPU, Aranyosi and Căldăraru, ECLI:EU:C:2016:198, Judgment of 4 Apr. 2016, para. 88.

${ }^{87} I d$. at para. 89.

${ }^{88} I$ d. at para. 92 .

${ }^{89}$ Under the CEAS, the ECJ applied a similar albeit less nuanced test; see ECJ, Joined Cases C-411 \& C-493/10, N.S., ECLI: EU:C:2011:865, Judgment of 21 Dec. 2011, para. 94. In recent jurisprudence, however, the Court increasingly neglected the criterion of "systemic deficiencies", see ECJ, Case C-578/16 PPU, C.K., ECLI:EU:C:2017:127, Judgment of 16 Feb. 2017; C-163/17, Jawo, ECLI:EU:C:2019:218, Judgment of 19 March 2019, paras. 87-88; Case C-297/17, Ibrahim, ECLI:EU:C:2019:219, Judgment of 19 Mar. 2019, paras. 87-88.

${ }^{90}$ Regulations dealing with matters of private international law often contain a public policy exception as a justification for the forum to refuse the application of foreign law or recognition of foreign judgments; see Art. 21 Regulation 593/2008 (Rome I); Art. 26 Regulation 864/2007 (Rome II); Art. 45(1)(a) Regulation 1215/2012 (Brussels I bis); Art. 23 Council Regulation 2201/2003 (Brussels II bis). The ECJ decided that such exceptions apply only in the case of "a manifest breach of a rule of law regarded as essential in the legal order of the State in which enforcement is sought or of a right recognised as being fundamental within that legal order", see ECJ, Case C-619/10, Trade Agency, ECLI:EU:C:2012:531, Judgment of 6 Sept. 2012, para. 51. See further ECJ, Case C-559/14, Meroni, ECLI:EU:C:2016:349, Judgment of 26 May 2016, para. 42; Case C-681/13, Diageo Brands, ECLI:EU:C:2015:471, Judgment of 4 Sept. 2015; para. 68; Case C-491/10 PPU, Aguirre Zarraga, ECLI:EU:C:2010:828, Judgment of 22 Dec. 2010, paras. 69-70; Case C-420/07, Apostolides, ECLI:EU:C:2009:271, Judgment of 28 Apr. 2009 , para. 59; Case C-394/07, Gambazzi, ECLI:EU:C:2009:219, Judgment of 2 April 2009, para. 27; Case C-7/98, Krombach, ECLI:EU: C:2000:164, Judgment of 28 Mar. 2000, para. 37.

${ }^{91}$ See Canor, supra note 73. 
Generally, the CJEU cannot directly assess all relevant policies in the issuing or rendering Member States, as these are not always covered by EU law (e.g. standards in detention facilities or the organization of the judiciary). Through the gateway of mutual recognition regimes, however, the CJEU can indirectly assess whether these Member States comply with essential EU standardseven in policy areas that seem to escape the scope of EU law. In this sense, the CJEU develops an indirect competence to review the situation in issuing or rendering Member States without facing restrictions like Article 51(1) CFR. ${ }^{92}$ That brings this construction close to the Reverse Solange doctrine-an indirect Reverse Solange.

As such, mutual recognition regimes involve a horizontal (Member State-Member State) as well as a vertical axe (EU-Member State). They operate in a triangle composed of the EU and (at least) two Member States, leading to an extended review competence of both Member State courts and the CJEU. Since the EU legal order acts-both concerning the relevant standards and institutionally - as a hinge linking and regulating the relationship between the Member States, this conception could also be termed Triangular Solange.

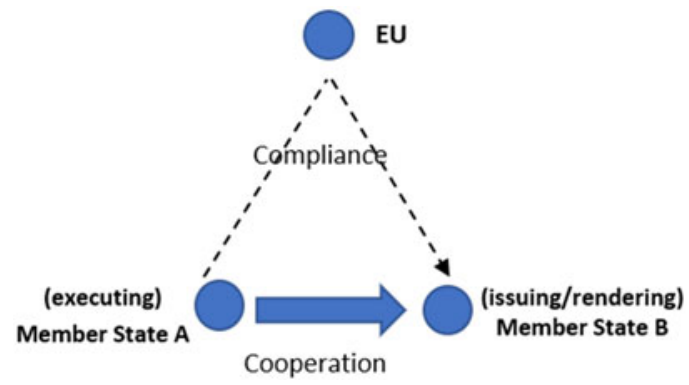

Figure 3: Triangular Solange

Eventually, this system allows for an indirect harmonization of autonomous Member State policies. If the issuing State does not comply with essential EU standards, it is indirectly affected-in form of a reflex-via the postponement of cooperation with the executing State. It is forced to align its policies if it wants to participate in these enhanced cooperation mechanisms. This indirect pressure, however, conflicts with the rationale underlying governance through mutual recognition. ${ }^{93}$ Compared to other modes of integration (like harmonization), mutual recognition is considered a better safeguard for the Member States' sovereignty, diversity, and political autonomy. ${ }^{94}$ These regimes aim at only providing a framework for cooperation without touching upon the substantive Member State policies they are supposed to coordinate. In order to respect this legislative decision against harmonization on the EU level, the CJEU has to interpret the indirectly harmonizing exceptions of cooperation in a restrictive manner.

\footnotetext{
${ }^{92} I d$. at $395-96$.

${ }^{93}$ See Elise Muir, Fundamental Rights: An Unsettling EU Competence, 15 HuM. Rights Rev. 25, 35-36 (2014). In the internal market context, see Miguel Poiares Maduro, So Close and Yet so Far: The Paradoxes of Mutual Recognition, 14 J. EUR. PUB. POL'y 814, 819 (2007).

${ }^{94}$ See e.g. Fritz W. Scharpf, European Governance: Common Concerns vs. the Challenge of Diversity, MPIfG, Working Paper No. 01/6 (2001), at 13; Susanne K. Schmidt, Mutual Recognition as a New Mode of Governance, 14 J. Eur. PUB. POL'y 667, 672 (2007). Yet, a certain degree of "regulatory competition" is always inherent in mutual recognition regimes, see Rizcallah, supra note 77, at 46; Maduro, supra note 93, at 816; Vassilis Hatzopoulos, From Hard to Soft: Governance in the EU Internal Market 15 CAMb. Y.B. EUR. LEg. STUD. 101, 110-13 (2013).
} 


\section{Implications for Backsliding Member States: The Judgment in L.M.}

How do these considerations relate to backsliding Member States? A preliminary reference of the Irish High Court from 12 March $2018^{95}$ tried to apply the above-mentioned system to the reforms of the judiciary in Poland. The case dealt with the surrender of a Polish national, who is wanted to face trial in Poland and was arrested in Ireland based on an EAW. The High Court did not rely on the Kovalkovasline of jurisprudence, but instead tried to apply the Aranyosi-test: Since the rule of law in Poland has been systematically damaged the respective person would be surrendered to face trial in a jurisdiction where an independent judge is not guaranteed. ${ }^{96}$ There were, however, two potential flaws difficult to reconcile with Aranyosi: First, despite systemic rule of law deficiencies, it was not clear whether the respective person was - upon surrender to Poland - individually exposed to a risk of facing a partisan trial (second prong of the Aranyosi-test). Second, even if his return had violated his rights under Article 47 CFR, the exception in Aranyosi concerns only absolute rights, ${ }^{97}$ which does not apply to Article 47. Aware of these obstacles, the High Court asked whether a national court can deny a request for surrender when it has found that the rule of law has been systematically breached in the issuing Member State, without performing the second step of the Aranyosi-test. ${ }^{98}$

Generally, the CJEU had to decide L.M. in a field of considerable tension between three antagonistic claims. On one hand, there were strong calls for limiting Aranyosi to its second prong and aligning the exceptions of cooperation under mutual recognition regimes with the ECtHR's jurisprudence in order to preserve coherence between the two systems. ${ }^{99}$ On the other hand, the Court was urged to reduce Aranyosi to its first prong concerning structural rule of law deficiencies, to assess the situation in Poland in a centralized manner, and to generally suspend the EAW framework with regard to Poland. ${ }^{100}$ This would have sent a strong message to backsliding Member States that the CJEU is ready to defend the Union's common values. A possible solution would have been to establish two non-cumulative exceptions based on either systemic or individual fundamental rights considerations. Yet, the Court had to keep the exceptions of cooperation as narrow as possible to respect the legislative decision against harmonization on the EU level and to guarantee the proper functioning of mutual recognition regimes.

Eventually, the Court found some middle-ground: First, it kept both prongs of the Aranyositest but extended it to the essence of other fundamental rights (like Article 47 CFR). ${ }^{101}$ Second, it rejected the possibility of generally suspending cooperation under the EAW framework and allowed only a postponing of individual EAW's. Third, it did not assess the situation in Poland itself, but left this delicate task to the referring court, thus (presumably) opting for a decentralized case-by-case review.

\section{Potential Weaknesses}

The great advantage of the Horizontal (indirect Reverse or Triangular) Solange approach is that it provides the CJEU with a hook to review the internal situation in the issuing Member State. Although the surrender itself is clearly within the scope of Union law as defined by Article

\footnotetext{
${ }^{95}$ Minister for Justice \& Equal. v. Celmer [2018] IEHC 119.

${ }^{96} I d$. at para. 128 .

${ }^{97}$ See Aranyosi and Căldăraru, Cases $404 \& 659 / 15$ PPU at para. 85.

${ }^{98}$ Minister for Justice \& Equal. v. Celmer [2018] IEHC 119, para. 145.

${ }^{99}$ The ECtHR requires postponing surrenders and transfer in case of individual fundamental rights violations under Art. 3 ECHR regardless of systemic deficiencies, see e.g. ECtHR [GC], Tarakhel v. Switzerland, App. 29217/12 (Nov. 4, 2014), para. 101; see further Anna Lübbe, 'Systemic Flaws' and Dublin Transfers: Incompatible Tests before the CJEU and the ECtHR?, 27 INT'L J. REFugEe L. 135 (2015).

${ }^{100}$ Michał Krajewski, Who is Afraid of the European Council? The Court of Justice's Cautious Approach to Independence of Domestic Judges, 14 Eur. Const. Rev. 792, 805-07 (2018). See also Petra Bárd \& Wouter van Ballegooij, Judicial Independence as a Precondition for Mutual Trust?, 9 New J. Eur. CrIM. L. 353 (2018); Wendel, Mutual Trust, Essence and Federalism, 15 EuR. Const. L. Rev. 17 (2019).

${ }^{101}$ Minister for Justice and Equality, Case C-216/18 PPU at para. 68.
} 
51(1) CFR, this is not necessarily the case for what is scrutinized under the Aranyosi-test. In L.M., neither the Polish judicial reforms nor the specific domestic criminal proceedings show any apparent link to EU law. Therefore, the Horizontal Solange approach as applied by the CJEU in L.M. could be considered a convincing instrument to address the illiberal developments in several Member States. Nevertheless, the CJEU's tripartite solution developed in L.M. reveals several shortcomings. Although the approach eventually allows for structural or institutional rule of law considerations and is not strictly limited to fundamental rights (3.1), the decentralized case-by-case review bears the risk of fragmentation (3.2) and might eventually even prove counter-productive (3.3).

\subsection{Only Fundamental Rights?}

Although the Court insisted on the second prong of the Aranyosi-test and relied on Article 47 CFR, L.M. is not a pure fundamental rights case, but a hybrid of individual fundamental rights assessment and general rule of law considerations. ${ }^{102}$ As Advocate General Tanchev noted, there is a certain division of labor between Article 47 CFR and Article 19(1)(2) TEU, which establishes the Member States' obligation to ensure effective judicial protection in the fields covered by Union law. While Article 19(1)(2) TEU ${ }^{103}$ addresses a "structural infirmity" in the Member States, Article 47 CFR concentrates on "individual or particularised incidences". ${ }^{104}$ Yet there are two reasons why such a clear division cannot be upheld with regard to the judgment in L.M. First, the Court seems to use Article 19(1)(2) TEU to inform the content of Article 47 CFR and vice versa. ${ }^{105}$ Although both provisions have a different function, Article 47 and Article 19(1)(2) have with regard to judicial independence a corresponding content. ${ }^{106}$ Second, an assessment of systemic and thus structural violations is inherent in the first prong of the Aranyosi-test. As such, the CJEU can establish structural EU standards that the Member States must observe when cooperating under EU mutual recognition regimes.

\subsection{The Risk of Fragmentation}

To the great discontent of many commentators, ${ }^{107}$ the CJEU neither assessed the first prong of the Aranyosi-test (systemic deficiencies) itself, nor did it suspend cooperation with Poland under the EAW framework in general. Instead, the Court seems to have opted for a decentralized case-bycase review. Indeed, a case-by-case review is demanded by the second prong of the Aranyosi-test that looks at the concrete risk of an individual fundamental rights violation. Based on the 10th recital of the Framework Decision's preamble, the Court concludes further that a general suspension of the EAW Framework is only possible via the Article 7 TEU procedure. ${ }^{108}$ Despite the partly legitimate criticism, ${ }^{109}$ a general suspension would have been, in my view, a far more detrimental

\footnotetext{
${ }^{102}$ But see Wendel, supra note 100, at 29; Theodore Konstadinides, Judicial Independence and the Rule of Law in the Context of Non-execution of a European Arrest Warrant: LM, 56 Common MKT. L. Rev. 743, 751 (2019).

${ }^{103}$ See infra Section D.II. for a more detailed examination of this provision.

${ }^{104}$ Opinion of Advocate General Tanchev at paras. 115-16, Case C-192/18, Commission v. Poland (June 20, 2019) (emphasis added); see further Advocate General Tanchev at paras. 92, 125, Case C-558/18, Miasto Łowicz (Sept. 24, 2019).

${ }^{105}$ Minister for Justice and Equality, Case C-216/18 PPU at paras. 35, 41, 53; Associação Sindical dos Juízes Portugueses, Case C-64/16 at paras. 35, 41; Commission v. Poland, Case C-619/18 R at paras. 49, 54. See also Opinion of Advocate General Tanchev at para. 85, Joined Cases 585, 624 \& 625/18, A.K. (June 27, 2019) ("there is a 'constitutional passarelle' between the two provisions, and the case-law concerning them inevitably intersects").

${ }^{106}$ See ECJ, Case C-682/15, Berlioz Investment Fund, ECLI:EU:C:2017:373, Judgment of 16 May 2017, para. 44 (“[T]he second subparagraph of Article 19(1) TEU ... corresponds to that right [Art. 47 CFR]"). See further ECJ, Case C-73/16, Puškár, ECLI:EU:C:2017:725, Judgment of 27 Sept. 2017, paras. 57-58; Case C-348/16, Sacko, ECLI:EU:C:2017:591, Judgment of 26 July 2017, paras. 29-30; Case C-685/15, Online Games, ECLI:EU:C:2017:452, Judgment of 14 June 2017, para. 54; Case C-243/15, Lesoochranárske zoskupenie VLK, ECLI:EU:C:2016:838, Judgment of 8 Nov. 2016, para. 50.

${ }^{107}$ Krajewski, supra note 100, at 797-99; Wendel, supra note 100, at 44-45; Bárd \& van Ballegooij, supra note 100; on a more positive note, see Konstadinides, supra note 102, at 761-62, 764.

${ }^{108}$ Minister for Justice and Equality, Case C-216/18 PPU at paras. 70-72.

${ }^{109}$ On the weaknesses of the Court's argument, see Krajewski, supra note 100, at 806 ("An act of secondary law, let alone its recital, cannot modify the power and obligation assigned to the Court ... by primary law").
} 
option. If the Court had generally suspended cooperation under the EAW framework with Poland, this would have led to a reinstitution of the pre-EAW extradition system - with national control mechanisms based on national fundamental rights. By keeping the EAW system alive with regard to Poland, the CJEU keeps this kind of inter-Member State cooperation within the scope of its review and control. This allows the CJEU to continue setting and defining relevant standards and benchmarks for the cooperation between the Member States and-in line with Horizontal Solange-to indirectly force the issuing Member State to comply with them. The Court's selfrestraint is thus a guarantee for maintaining EU law as a relevant standard.

Unfortunately, the CJEU did not assess the rule of law in Poland itself-as it did, for example, with systemic deficiencies in N.S. ${ }^{110}$ _but left this delicate task to the Member States' courts. A decentralized control by each Member State, however, could lead to diverging or incompatible decisions throughout the EU judicial space and jeopardize the uniform application of Union law. Further, bilateral control mechanisms are generally alien to the EU legal order. ${ }^{111}$ Therefore, at least the standards for review must be set and strictly defined in a centralized manner and in much greater detail by the CJEU. ${ }^{112} \mathrm{~A}$ reference to the CJEU becomes even more important as it is the only way for the "accused" Member State to defend itself (via an observation). In national proceedings, a foreign Member State has practically no possibility to intervene. This ensures a certain equality of arms, which is an element of the rule of law in itself. ${ }^{113}$

\subsection{Negative Incentives}

Following the L.M. judgment, national courts can now assess the rule of law compliance of Member States issuing an EAW within the frame of individual actions. Allowing Member States to postpone their cooperation with those compromising the rule of law in concrete cases seems a welcome development and should be extended to other mutual recognition regimes. Yet postponing cooperation only works if it presents an incentive for Member States to comply with EU standards. Poland's, Hungary's or Romania's isolation from the Dublin system, for example, could be perceived as a courtesy. ${ }^{114}$ Seen in this light, Horizontal Solange can only be used in selected areas of cooperation. The sole regime that could provide serious leverage is the cooperation in civil matters. Unfortunately, the public policy exceptions in these mutual recognition regimes are not developed enough to provide an instrument with bite against illiberal developments in the Member States ${ }^{115} \ldots$ yet: In this sense, much will depend on future

\footnotetext{
${ }^{110}$ The Court already assessed the existence of "systemic deficiencies" in several cases, see N.S., Joined Cases 411 \& $493 / 10$ at paras. 86, 89, 94, 106, Aranyosi and Căldăraru, Joined Cases 404 \& 659/15 PPU and ECJ, Case C-220/18 PPU, Generalstaatsanwaltschaft (Conditions de détention en Hongrie), ECLI:EU:C:2018:589, Judgment of 25 July 2018. Generally, the Court can decide on the degree of specificity, see Koen LenAerts, IgnaCE Maselis \& KathleEN Gutman, EU Procedural Law 231 (2014); Takis Tridimas, Constitutional Review of Member State Action: The Virtues and Vices of an Incomplete Jurisdiction, 9 ICON 737, 749 (2011).

${ }^{111}$ This explains the little practical relevance of the Art. 259 TFEU procedure. For a different conception, see Dimitry Kochenov, Biting Intergovernmentalism: The Case for the Reinvention of Article 259 TFEU to Make It a Viable Rule of Law Enforcement Tool, 7 Hague J. Rule L. 153 (2015); Ernst Hirsch Ballin, Mutual Trust. The Virtue of ReciprocityStrengthening the Acceptance of the Rule of Law through Peer Review, in REINFORCING RULE OF LAW OvERSIGHT, supra note 10, 133.

${ }^{112}$ For a division of labor according to the two prongs of the Aranyosi-test, see Wendel, supra note 100 , at 41.

${ }^{113} I d$. at 43 .

${ }^{114}$ Poland refused to fulfil its Dublin-quotas. The European Commission already initiated infringement proceedings, see European Commission, Relocation: Commission Refers the Czech Republic, Hungary and Poland to the Court of Justice (Dec. 7, 2017), europa.eu/rapid/press-release_IP-17-5002_en.htm. The case is currently pending before the ECJ, see Commission v. Poland (C-715/17). See also the case brought by Hungary and Slovakia against the relocation of asylum seekers, ECJ, Joined Cases C-643 \& 647/15, Slovak Republic and Hungary v. Council, ECLI:EU:C:2017:631, Judgment of 6 Sept. 2017. See further Wendel, supra note 100 , at 36 .

${ }^{115}$ On this, see Lenaerts, supra note 77, at 824 et seq.; Eva Storskrubb, Mutual Trust and the Dark Horse of Civil Justice, 20 CAmb. Y.B. Eur. LEG. STUD. 179, 189 et seq. (2018); Matthias Weller, Mutual Trust: In Search of the Future of European Union Private International Law, 11 J. PrIV. INT'L L. 64, 90 et seq., 97-100 (2015).
} 
academic work and the courts' willingness to rely on these mechanisms in order to set a respective development in motion.

\section{Towards a More Comprehensive Approach: Construing the Judicial Applicability of Article 2 TEU}

Without any doubt, Reverse and Horizontal Solange constitute important and viable paths for addressing illiberal developments in the Member States before national courts and the CJEU. At their core, both Solange approaches aim at protecting the Union's common values even in situations that seem to escape the scope of EU law. Yet, they are inherently restricted to either fundamental rights considerations or rather limited areas of cooperation (mutual recognition regimes). Without rejecting or excluding these proposals, I argue that their key aim can be better achieved by following a more comprehensive approach: Relying on Article 2 TEU itself. That provision states at a prominent position: "The Union is founded on the values of respect for human dignity, freedom, democracy, equality, the rule of law and respect for human rights ... These values are common to the Member States ..."

Article 2 TEU presents three features qualifying it especially for countering the illiberal tendencies in EU Member States. First, it has an unrestricted scope of application. It applies to any Member State act irrespective of any link to (other) EU law. ${ }^{116}$ Second, it is not confined to ensuring "respect for human rights", but also captures developments threatening democracy or the rule of law in their structural, institutional dimension. Third, a justiciable Article 2 TEU could be invoked not only by Union citizens before national courts or in the context of mutual recognition regimes but in virtually any judicial proceeding before the CJEU or national courts.

The judicial applicability of Article 2 TEU, however, is far from self-evident. Considering the importance of the issues at stake, one would expect to find a thorough academic discussion and analysis of Article 2 TEU. Unfortunately, the state of scholarship concerning the famed Article 2 TEU itself is relatively low. Besides some more general contributions, ${ }^{117}$ there are practically no works addressing the provision and its judicial applicability as such. ${ }^{118}$

After discussing some of the uncertainties related to Article 2 TEU (I.), this contribution will demonstrate how its judicial applicability could be construed in light of the CJEU's recent case

\footnotetext{
${ }^{116}$ In rare agreement, see European Commission, A New EU Framework to Strengthen the Rule of Law, COM(2014) 158 final, at 5; and Council of the European Union, Opinion of the Legal Service: Commission's Communication on a New EU Framework to Strengthen the Rule of Law: Compatibility with the Treaties, 10296/14, para. 17. See also European Commission, Communication on Art. 7 of the Treaty on European Union, $\operatorname{COM}(2003) 606$ final, at 5; European Convention, Draft of Articles 1 to 16 of the Constitutional Treaty, CONV 528/03, at 11; Marcus Klamert \& Dimitry Kochenov, Article 2 TEU, in The Treaties and the Charter of Fundamental Rights-A Commentary 22, 25 (Manuel Kellerbauer, Marcus Klamert \& Jonathan Tomkin eds., 2019); Meinhard Hilf \& Frank Schorkopf, Art. 2 EUV, in Das Recht DeR EuropäIsCHen Union para. 18 (Eberhard Grabitz, Meinhard Hilf \& Martin Nettesheim eds., 2018); Christian Calliess, Art. 2 EUV, in Euv/AEuv para. 10 (Christian Calliess \& Matthias Ruffert eds., 5 ${ }^{\text {th }}$ ed., 2016); Frank SCHORKOPF, HOMOGENITÄT IN DER EUROPÄISCHEN UNION 69 et seq. (2000).

${ }^{117}$ See e.g. Egils Levits, Die Europäische Union als Wertegemeinschaft, in EUROPA 4.0239 (Thomas Jaeger ed., 2018); Andreas Voßkuhle, The Idea of the European Community of Values (2017); Joseph H.H. Weiler, Taking (Europe's) Values Seriously, in LAw BeYOND THE STATE 93 (Rainer Hofmann \& Stefan Kadelbach eds., 2016); Armin von Bogdandy, Founding Principles, in Principles of European Constitutional LaW 11, 21 (Jürgen Bast \& Armin von Bogdandy eds., $2^{\text {nd }}$ ed., 2010); Andrew T. Williams, Taking Values Seriously: Towards a Philosophy of EU Law, 29 OXford J. LEG. STUD. 549 (2009); Christian Calliess, The Transnationalization of Values by European Law, 10 GERMAN L.J. 1367 (2009). On European values more generally, see ANDrEW T. Williams, The Ethos of Europe: VALUES, LAW and Justice in the EU (2010); Chritsof Mandry, Europa als Wertegemeinschaft (2009); Simon Labayle, Les VALEURS DE L'Union EUROPÉENNE (forthcoming 2020).

${ }^{118}$ For brief overviews of the Court's jurisprudence, see e.g. Koen Lenaerts, Die Werte der Europäischen Union in der Rechtsprechung des Gerichtshofs der Europäischen Union, 44 EUROPAISCHE GRUNDRECHTE-ZEITSCHRIFT 639 (2017); Salvatore Nicolosi, The Contribution of the Court of Justice to the Codification of the Founding Values of the European Union, 51 Rev. Der. COM. EUR. 613 (2015).
} 
law (II.). Certainly, the proposal will raise criticism for being methodologically unsound and-due to Article 2 TEU's unrestricted scope of application - for uprooting the federal equilibrium between the EU and the Member States. In anticipating such objections, this Article will demonstrate that the activation of Article 2 TEU can be anchored in sound legal methodology and propose ways for limiting the judicially applicable Article 2 TEU to safeguard the federal equilibrium (III.).

\section{Uncertainties Surrounding the Application of Article 2 TEU}

The uncertainties surrounding Article 2 TEU can be narrowed down to three key points: Its nature (I. 1), direct effect (I. 2), and the jurisdiction of the CJEU (I. 3).

\section{Nature: Do Article 2 TEU Values Have Any Legal Effect?}

Scott Shapiro once wrote that "there is often no way to resolve specific disagreements about the law without first resolving disagreements about the nature oflaw". ${ }^{119}$ This holds especially true for an overarching provision like Article 2 TEU. By using the term "value", the Treaty drafters introduced a rather ambiguous notion into EU primary law. ${ }^{120}$ Values are widely used in very different contexts: Law, economics, philosophy, ethics, religion, sociology, psychology ... values are very close to what Uwe Pörsken called "plastic words"121_empty formulas that mean everything and nothing. As contextdependent shapeshifters or chameleons, they can be used in different fields with different meanings.

In law, values are generally juxtaposed with "principles" and "rules", ${ }^{122}$ and in the Treaties especially with "competences" and "objectives". ${ }^{123}$ Yet, values somehow transcend these dichotomies without revealing their precise character. One might justifiably ask why the drafters burdened the Treaties with such a can of worms. Unfortunately, analyzing the European Convention's travaux is of no further use. Although several members saw the uncertainties tied to values and suggested replacing them with "principles", ${ }^{24}$ the term remained in the draft without being grounded in a solid theory of what they were supposed to be. ${ }^{125}$

\footnotetext{
${ }^{119}$ SCOTT SHAPIRO, LEGALITY 29 (2011).

${ }^{120}$ See already draft Art. I-2 of the Constitution of Europe and European Council, Laeken Declaration of 15 Dec. 2001 on the Future of the European Union, 2001 Bull. EU 12/19. Before the Constitution, the term "principles" was used, see Art. 6(1) Nice, Art. F(1) Amsterdam. For the reference to "values" in the context of the Austria crisis, see Martti Ahtisaari, Jochen Frowein \& Marcelino Oreja, Report on the Austrian Government's Commitment to the Common European Values (The Wise Men Report), 40 InT'L Leg. Materials 102, at 120 (2001) (paras. 115, 117) and of EU enlargement, see Declaration on European Identity, 1973 Bull. EC 12/118 (Dec. 14, 1973); Conclusions of the Presidency, European Council, at 7.A.iii) (June 21-22, 1993).

${ }^{121}$ See Uwe Pörsken, Plastic Words: The Tyranny of a Modular Language 22, 26 (2004) placing "values" in one line with notions like "identity" or "substance".

${ }^{122}$ On how to distinguish these categories, see e.g. JÜrgen Habermas, Between Facts AND Norms 255 et seq. (1996); Robert Alexy, A Theory of Constitutional Rights 86 et seq. (2009); Ronald Dworkin, Taking Rights Seriously 38 et seq. (2013); critically, ANDrÁs JAKAB, EUROPEAN CONSTITUTIONAL LANGUAGE 368 (2016).

${ }^{123}$ See Joris Larik, From Speciality to a Constitutional Sense of Purpose: On the Changing Role of the Objectives of the European Union, 63 INT'L \& CoMP. L.Q. 935 (2014).

${ }^{124}$ European Convention, Reactions to draft Articles 1 to 16 of the Constitutional Treaty, CONV 574/1/03, REV 1, at 17 . See e.g. the suggestions for amendment by Ernâni Lopes and Manuel Lobo Antunes: "Human dignity, liberty ... are principles and not mere values. Only principles may be legally binding and its violation invoked before a Court"; suggestion for amendment by Meglena Kuneva: "Il serait préférable de garder la notion de 'principes', bien connue du droit communautaire et qui est employée par l'article 6 du TUE.” See also Plenary Session: Debate on Draft Articles 1 to 16 (Feb. 27-28, 2003), www.europarl.europa.eu/Europe2004/textes/verbatim_030227.htm, see e.g. 4-018 Einem (Parl.-AT): "Herr Präsident! ... wir treten dafür ein, lieber von Grundsätzen - principles - statt von Werten - valeurs zu sprechen" and 4-083 - Kutskova (Gouv.-BG): "Concerning Article 2, we consider it preferable to keep the notion of principles typical of the acquis".

${ }^{125}$ Hilf \& Schorkopf, supra note 116, at para. 21 ("noch nicht ausgereifte Durchformung des Unionsrechts"). With regard to "principles," see von Bogdandy, supra note 117, at 21 ("missing overarching conception of the authors of the Treaty").
} 
As such, it is not self-evident that Article 2 TEU values unfold legal effects. Some even doubt their status as law. ${ }^{126}$ These doubts, however, are hardly convincing. The values of Article 2 TEU are laid down in the operative part of a legal text. They are applied in legally determined procedures by public institutions (Article 7 and 49(1) TEU) and their disregard leads to sanctions, which are of legal nature. In fact, the legal framing of the Union's values seems almost inevitable. The rule of law warrants that normative requirements enforced by public institutions are laid down in the form of law. Otherwise, the mechanisms of Article 7 or Article 49 TEU would provide political morality with public authority without making it subject to any constitutional limitations. ${ }^{127}$ For this reason, Article 2 TEU values are necessarily part of EU law.

Yet, the views on their exact nature differ considerably. First, Article 2 values can be understood as rules, because they form legal parameters relevant for both the sanctioning mechanism under Article 7 and the admission procedure under Article 49 TEU. Second, one could argue that values are in fact principles. ${ }^{128}$ Indeed, the Treaty drafters used the notions of values and principles in a rather undifferentiated way. ${ }^{129}$ This supports the view that Article 2 TEU is merely a continuation of the CJEU's caselaw on general principles. ${ }^{130}$ Finally, one could perceive Article 2 TEU as a new form of legal category, which still has to be determined. Whatever the response to this question might be, one thing seems rather clear: Article 2 TEU does not contain mere rough ideals-it unfolds legal effects.

\section{Direct Effect: Are Article 2 TEU Values Directly Applicable?}

Nevertheless, the acknowledgment of legal effects does not necessarily entail Article 2 TEU's direct applicability (or even justiciability). Since the values are extremely vague and open, ${ }^{131}$ it is not entirely clear whether Article 2 TEU fulfils the essential criteria for direct effect: A Treaty provision must be precise, clear, and unconditional. ${ }^{132}$ With regard to the rule of law, Dimitry Kochenov and Laurent Pech put these concerns in a nutshell: "The rule of law ... is not $a$ rule of law actionable before a court."133

Let's take a step back: How could Article 2 TEU be applied in the abstract? Following a broader reading, one could understand direct effect as simply implying the judicial applicability of EU law, irrespective of whether the provision creates specific legal obligations-it simply has

\footnotetext{
${ }^{126}$ Such uncertainties are provoked first and foremost by the Commission itself, see European Commission, supra note 3, at para. 1 ("The Commission, beyond [!] its task to ensure the respect of EU law, is also responsible ... for guaranteeing the common values of the Union") (emphasis added). For such doubts, see also Möllers \& Schneider, supra note 14, 125; Levits, supra note 117, at 263; Kochenov, supra note 56, at 149.

${ }^{127}$ von Bogdandy, supra note 13, at 522. On the tension between the Art. 7 TEU procedure and the rule of law, see Matthias Niedobitek, Right and Duty to Pursue the "Wrongdoer" and a Possible Abuse of Art. 7 TEU, in Liability of Member States, supra note 118 , at $233,241$.

${ }^{128}$ von Bogdandy, supra note 117, at 22. See also Roberto Baratta, La "communauté de valeurs" dans l'ordre juridique de l'Union européenne, REVUe des AfFAIRES EuropéENnes 81, 89 (2018); Rudolf Streinz, Principles and Values in the European Union, in Liability of Member States for the Violation of Fundamental Values 11 (Armin Hatje \& Lubos Tichý eds., 2018); Nicolosi, supra note 118, at 637; Stelio Mangiameli, The Union's Homogeneity and Its Common Values, in THE European Union After LisBon 21 (Hermann-Josef Blanke \& Stelio Mangiameli eds., 2012).

${ }^{129}$ This becomes especially apparent in the preamble to the TEU. On one hand, the Treaty drafters draw "inspiration from the ... universal values of the inviolable and inalienable rights of the human person, freedom, democracy, equality and the rule of law". On the other hand, they confirm "their attachment to the principles of liberty, democracy and respect for human rights ... and of the rule of law" (emphasis added).

${ }^{130}$ Takis Tridimas, The General Principles of Eu Law 15 ( $2^{\text {nd }}$ ed., 2006).

${ }^{131}$ On the need for a "non-controversial" and thus deliberately open set of values, see European Convention, supra note 116, at 11 .

${ }^{132}$ See van Gend \& Loos, Case C-26/62; more recently, ECJ, Case C-176/12, Association de médiation sociale, ECLI:EU: C:2014:2, Judgment of 15 Jan. 2014, para. 36. On the state of the art, see Paul Craig \& Grainne De Búrca, Eu LaW 192 (6 $6^{\text {th }}$ ed., 2015).

${ }^{133}$ Dimitry Kochenov \& Laurent Pech, Monitoring and Enforcement of the Rule of Law in the EU, 11 EUR. CONST. L. REV. 512, 520 (2015).
} 
to be taken into consideration by a court. ${ }^{134}$ This conforms with recent trends in the CJEU's jurisprudence. Concerning the direct effect of Charter rights, the Court started to distinguish between two categories: ${ }^{135}$ First, mandatory effect, meaning that a provision is "sufficient in itself" to entail a specific right or obligation; ${ }^{136}$ and second, the unconditional nature, meaning that a right does not need "to be given concrete expression by the provisions of EU or national law". ${ }^{137}$

According to this recent understanding, the application of Article 2 TEU faces three options. First, Article 2 TEU could be perceived as mandatory and unconditional and thus apply as a stand-alone provision. ${ }^{138}$ Second, Article 2 TEU could lack a mandatory effect but still be unconditional. In this case, Article 2 TEU could be considered by the CJEU or national courts through some sort of (non-binding?) value-oriented interpretation of EU and national law. Finally, a third option would be that Article 2 TEU is mandatory but not unconditional. It would need to be applied with a more specific provision giving concrete expression to the values enshrined in Article 2 TEU (combined approach). ${ }^{139}$ Such a combined approach could be construed in two ways: On one hand, Article 2 TEU could be applied directly but informed by a more specific provision. On the other hand, one could apply a specific provision of EU law giving expression to a value enshrined in Article 2 TEU thus operationalizing the latter.

\section{Jurisdiction: Does the CJEU Have Competence to Review Member States' Value Compliance?}

Even if Article 2 TEU has direct effect and creates directly applicable (and thus in principle justiciable) obligations for the Member States, it is not said that the CJEU has jurisdiction to assess and enforce Article 2 TEU compliance in the Member States. Generally, the Court's competence encompasses the interpretation and assessment of the "law" (Article 19(1)(1) TEU). This includes Union law in all its shapes, forms, and manifestations. ${ }^{140}$ In this light, it seems very likely that the Court has a competence to interpret and assess Article 2 TEU as well. Yet it is highly debated whether the Article 7 TEU procedure and the Court's limited competence to review the latter (Article 269 TFEU) bar an assessment and enforcement of

\footnotetext{
${ }^{134}$ Christian Wohlfahrt, Die Vermutung Unmittelbarer Wirkung Des Unionsrechts 14, 162 (2016); Pierre Pescatore, The Doctrine of Direct Effect: An Infant Disease of Community Law, 8 EUR. L. REv. 155 (1983) (“'direct effect' boil[s] down to a question of justiciability. A rule can have direct effect whenever its characteristics are such that it is capable of judicial adjudication").

${ }^{135}$ See e.g. ECJ, Case C-684/16, Max-Planck-Gesellschaft, ECLI:EU:C:2018:874, Judgment of 6 Nov. 2018, para. 74; Case C-569/16, Bauer, ECLI:EU:C:2018:871, Judgment of 6 Nov. 2018, para. 85 ("Article 31(2) of the Charter, is ... both mandatory and unconditional in nature") (emphasis added).

${ }^{136}$ ECJ, Case C-414/16, Egenberger, ECLI:EU:C:2018:257, Judgment of 17 Apr. 2018, paras. 76-77; Case C-193/17, Cresco Investigation, ECLI:EU:C:2019:43, Judgment of 22 Jan. 2019, para. 77.

${ }^{137}$ Max-Planck-Gesellschaft, Case C-684/16 at paras. 74, 78; Bauer, Case C-569/16 at paras. 85, 89.

${ }^{138}$ For an approach relying directly on Art. 2 TEU yet specified i.a. via the Copenhagen Criteria, see Hillion, supra note 13, at 66 et seq. This is further what a "systemic infringement action" proposed by Scheppele or Skouris boils down to, see Scheppele, supra note 21; Skouris, supra note 14, at 50. A recent preliminary reference by a Bulgarian court gives an opportunity for clarifying these issues. The question is whether a Member State court can "directly invoke and directly apply Article 2 TEU", see Corporate Commercial Bank, en liquidation (C-647/18).

${ }^{139}$ For first sketches, see Carlos Closa \& Dimitry Kochenov, Reinforcing the Rule of Law Oversight in the European Union, in Strengthening the Rule of LAW, supra note 14, 173, 182-184; Pech et al., supra note 14, at 198; Enzo Cannizzaro, I ruolo della Corte di giustizia nella tutela dei valori dell'Unione europea, in LiBER AMICORUM ANTONIO TIZZANO 159 (2018).

${ }^{140}$ The ECJ has assessed recommendations (ECJ, Case C-322/88, Grimaldi, ECLI:EU:C:1989:646, Judgment of 13 Dec. 1989 , paras. 7-8; Case C-16/16 P, Belgium v. Commission; ECLI:EU:C:2018:79, Judgment of 20 Feb. 2018, para. 44), communications (ECJ, Case C-57/95, France v. Commission, ECLI:EU:C:1997:164, Judgment of 20 Mar. 1997, para. 23), guidelines (ECJ, C-233/02, France v. Commission, ECLI:EU:C:2004:173, Judgment of 23 Mar. 2004, para. 40), memoranda (ECJ, Case C-258/ 14, Florescu, ECLI:EU:C:2017:448, Judgment of 13 June 2017, para. 30) and even mere announcements (ECJ, Case C-62/14, Gauweiler, ECLI:EU:C:2015:400, Judgment of 16 June 2015, para. 27).
} 
Union values via the Article 258 or 267 TFEU procedures ${ }^{141}$-especially beyond the scope of application of (other) EU law. ${ }^{142}$

Nevertheless, there are good arguments in favor of the Court's jurisdiction. While the former Treaties have kept the EU's foundational principles out of the Court's reach, ${ }^{143}$ the Lisbon Treaty does not contain any comparable limitation with regard to Article 2 TEU. First, Article 269 TFEU is an exception to the CJEU's general competence under Article 19(1)(1) TEU, which must be interpreted narrowly. ${ }^{144}$ Second, the political Article 7 TEU and the judicial Article 258/267 TFEU procedures have different objects and consequences. Article 7 TEU concentrates on a political situation and ultima ratio entails the suspension of Member States' rights eventually leading to a sort of "quarantine". ${ }^{145}$ In contrast, the Court adjudicates an individual case and its sanctioning powers are limited to Article 260 TFEU (penalty payments). For this reason, there is no identity between the judicial and the political procedures imposing the latter's exclusivity.

\section{Reviewing and Enforcing Member States' Value-Compliance in Judicial Proceedings}

In an emerging line of jurisprudence, the CJEU could be seen as resolving these uncertainties by developing Article 2 TEU into a judicially applicable provision justiciable before the Court. The pierre fondatrice of this emerging jurisprudence is the judgment in Associação Sindical dos Juizes Portugueses (“ASJP”). In this seminal case, the Court established the Member States' obligation to guarantee the judicial independence of de facto the whole national judiciary irrespective of any specific link to EU law (II.1.). Although this stance can also be reconstrued as a manifestation of the well-established effet utile rationale (II.2.), I propose a different reading relying on Article 2 TEU. According to my understanding, the Court opted for a combined approach, operationalizing Article 2 TEU through a specific provision of EU law. This allows to review and sanction any Member State action violating the Union's common values in judicial proceedings before the CJEU-irrespective of whether this action reveals any link to other EU law (II.3.).

\section{The Groundbreaking Judgment in ASJP}

On its face, ASJP seems like a rather innocent case. A Portuguese court asked the CJEU whether salary reductions for judges adopted in the context of an EU financial assistance program violated judicial independence. As already indicated above, ${ }^{146}$ there are two Treaty provisions guaranteeing judicial independence: Article 47 CFR and Article 19(1)(2) TEU. The former only operates under the scope defined in Article 51(1) CFR. The salary reductions were part of spending cuts conditional for financial assistance under the EU financial crisis mechanisms. Since the Court already applied the Charter in comparable situations, ${ }^{147}$ Advocate General Øe proposed to grasp this thin

\footnotetext{
${ }^{141}$ For an argument in favor of the Court's jurisdiction, see Opinion of Advocate General Tanchev at para. 50, Case C-619/ 18 R, Commission v. Poland (Apr. 11, 2019); Schmidt \& Bogdanowicz, supra note 21, at 1069-73; Hilf \& Schorkopf, supra note 116, at para. 46; Hillion, supra note 13, at 71-73; Müller, supra note 15, at 146; Scheppele, supra note 21, at 114; Skouris, supra note 14, at 50; Waelbroeck \& Oliver, supra note 14, at 335; Claudio Franzius, Der Kampf um Demokratie in Polen und Ungarn, 71 Die ÖfFentliche Verwaltung 381, 386 (2018). But see Levits, supra note 117, at 262; Nicolosi, supra note 118, at 643; Bernd Martenczuk, Art. 7 EUV und der Rechtsstaatsrahmen als Instrument der Wahrung der Grundwerte der Union, in VerfassungSKRISEN IN DER EUROPÄISCHEN UnION 41, 45-46 (Stefan Kadelbach ed., 2018).

${ }^{142}$ Against the Court's jurisdiction beyond the scope of EU law, Lenaerts \& Gutiérrez-Fons, supra note 56, at 774.

${ }^{143}$ According to Art. 46(d) TEU (Nice), the ECJ was only competent for what was then Art. 6(2) TEU (Nice) but not for the "principles" laid down in Art. 6(1) TEU (Nice). The Court nonetheless relied on them, see ECJ, Case C-402/05 P, Kadi, ECLI: EU:C:2008:461, Judgment of 3 Sept. 2008, para. 303.

${ }^{144}$ On Art. 269 TFEU as "unconstitutional constitutional law," see Thomas Giegerich, Die Unabhängigkeit der Gerichte als Strukturvorgabe der Unionsverfassung, 22 ZEUs 61, 80 (2019).

${ }^{145}$ Frank Schorkopf, Wertesicherung in der Europäischen Union, 51 EUROPARECHT 147 (2016).

${ }^{146}$ See discussion supra Section C.II. 3.1

${ }^{147}$ See e.g. Florescu, Case C-258/14.
} 
material link and rely on the CFR. ${ }^{148}$ The CJEU could have followed this approach and ASJP would have disappeared discretely as another clarification of the meandering post- $A$ kerberg Fransson case law. Yet, this is not what happened. The Court referred to Article 19(1)(2) TEU, which stipulates that "Member States shall provide remedies sufficient to ensure effective legal protection in the fields covered by Union law". Such effective legal protection presupposes an independent judiciary. ${ }^{149}$

According to the Court, this obligation applies "irrespective of whether the Member States are implementing Union law, within the meaning of Article 51(1)". ${ }^{150}$ This is already indicated by the different wording of both provisions. Article 19(1)(2) TEU limits its scope to "the fields covered by Union law", whereas the Charter applies to "situations ... within the scope of European Union law". 151 "Fields" are different from "situations". According to this semantic difference, "fields covered by Union law" could be understood in a more extensive manner. ${ }^{152}$ But how broad should the scope of Article 19(1)(2) TEU be? The Court refers to the preliminary ruling mechanism under Article 267 TFEU: "[T]hat mechanism may be activated only by a body responsible for applying EU law which satisfies, inter alia, that criterion of independence". ${ }^{153}$ "Responsible for applying EU law" includes all authorities which are potentially in the situation of applying it. ${ }^{154}$ This means practically every Member State court. ${ }^{155}$ For Article 19(1)(2) TEU to be triggered, it is not necessary that the respective Member State court actually adjudicates a matter of EU law in the specific case at hand; the mere potentiality of dealing with such matters suffices.

As such, Article 19(1)(2) TEU reaches even situations which do not present any other link to EU law. Accordingly, ASJP has been interpreted as establishing a "quasi-federal standard"156 for judicial independence. How does the Court justify this ample scope? A thorough analysis of ASJP reveals two (complementary?) rationales, a functional and axiological one. ${ }^{157}$ The CJEU's reading of Article 19(1)(2) TEU is justified both by a recourse to the functioning of the EU's judicial system and the values enshrined in Article 2 TEU.

\footnotetext{
${ }^{148}$ Opinion of Advocate General Øe at paras. 43-53, Case C-64/16, Associação Sindical dos Juízes Portugueses (May 18, 2017).

${ }^{149}$ Associação Sindical dos Juízes Portugueses, Case 64/16 at para. 36.

${ }^{150} I d$. at para. 29 (emphasis added).

${ }^{151}$ Åkerberg Fransson, Case C 617/10 at para. 19. For a more recent example, see ECJ, Case C-117/14, Nisttahuz Poclava, ECLI:EU:C:2015:60, Judgment of 5 Feb. 2015, para. 29.

${ }^{152}$ For this interpretation, see Koen Lenaerts, Upholding the Rule of Law through Judicial Dialogue, 38 Y.B. EUR. L. (2019); Id., On Judicial Independence and the Quest for National, Supranational and Transnational Justice, in THE ART OF JUDICIAL Reasoning. Festschrift in Honour of Carl Baudenbacher 155, 163 (Gunnar Selvik et al. eds., 2019); Thomas von Danwitz, Values and the rule of law: Foundation of the European Union-an Inside Perspective from the ECJ, REVUE DU Droit de L'Union EuropéEnNe 263, 269 (Issue 4) (2018); Levits, supra note 117, at 268. See also Laurent Pech \& Sébastien Platon, Judicial Independence under Threat: The Court of Justice to the Rescue in the ASJP Case, 55 Common Мкт. L. Rev. 1827, 1837 (2018); Giegerich, supra note 144, at 76; Alberto Miglio, Indipendenza del giudice, crisi dello stato di diritto e tutela giurisdizionale effettiva, 12 DIRITTI UMANI E DIRITTO INTERNAZIONALE 421, 426 (2018). On the implications of different scopes under Art. 19(1)(2) TEU and the Charter, see Luke D. Spieker, Commission v. Poland-A Stepping Stone Towards a Strong "Union of Values"?, Verfassungsblog (May 30, 2019); Matteo Bonelli \& Monica Claes, Judicial Serendipity: How Portuguese Judges Came to the Rescue of the Polish Judiciary, 14 Eur. Const. L. Rev. 622, 630-32 (2018).

${ }^{153}$ Associação Sindical dos Juízes Portugueses, Case 64/16 at para. 43 (emphasis added); see now even more clearly Commission v. Poland, Case C-619/18 R at para. 51.

${ }^{154}$ See also Commission v. Poland, Case C-619/18 R, para. 51; Advocate General Tanchev at paras. 87-88, 94, 125, Case C558/18, Miasto Łowicz (Sept. 24, 2019).

${ }^{155}$ Similarly, von Danwitz, supra note 152, at 269; Pech \& Platon, supra note 152, at 1838; Bonelli \& Claes, supra note 152, at 623.

${ }^{156}$ Pech \& Platon, supra note 152, at 1847; Stanislas Adam \& Peter Van Elsuwege, L'exigence d'independance du juge, paradigme de l'Union européenne comme union de droit, Journal DE DroIt EuropéEn 334, 341 (2018).

${ }^{157}$ Retracing these two rationales, see Advocate General Tanchev at para. 92, Case C-558/18, Miasto Łowicz (Sept. 24, 2019). See also von Bogdandy \& Spieker, supra note 60 .
} 


\section{The Functioning of the EU's Judicial System}

At first sight, the CJEU seems to employ the well-established effet utile rationale. First, the Court refers to the functioning of the preliminary reference procedure in Article 267 TFEU. National courts have an indispensable position in the effective and uniform application of EU law. ${ }^{158}$ As they are obliged to apply EU law in the respective Member States even where it may conflict with national law, they are considered to be the first "Union courts"159 and as such an "arm of EU law". ${ }^{160}$ Such a system cannot work if Member State courts are not independent. Not without reason, one of the key pre-conditions for a court to be eligible for launching preliminary references is its independence. ${ }^{161}$

Second, the rationale behind Article 19(1)(2) TEU supports the Court's findings. Despite a limited relaxation of the demanding locus standi criteria for individual actions before the CJEU (see Article 263(4) TFEU), ${ }^{162}$ the drafters of the Lisbon Treaty retained the decentralized judicial system based on both the CJEU and Member State courts. ${ }^{163}$ The function of Article 19(1)(2) TEU is to ensure that this diffused judicial system works and that no protection gaps arise. ${ }^{164}$ This necessarily enables the CJEU to specify and harmonize Member States' provisions regarding judicial remedies and procedures. ${ }^{165}$ These two considerations seem to strongly indicate that the CJEU is relying on its well-known effet utile argument. ${ }^{166}$ In this light, ASJP could be read as an further step in the jurisprudential line of Les Verts, Simmenthal, Opinion 1/09 and Unibet.

\section{The Judicial Applicability of Article 2 TEU}

Yet there is another, potentially groundbreaking explanation for the ample scope of Article 19(1)(2) TEU leaving the beaten tracks and venturing into uncharted territories of EU law. At

\footnotetext{
${ }^{158}$ Van Gend en Loos, Case C-26/62. See also ECJ, Case C-284/16, Achmea, ECLI:EU:C:2018:158, Judgment of 6 Mar. 2018 , para. 36; Opinion 2/13, EU Accession to the ECHR II, Opinion 2/13, para. 176; Opinion 1/09, Unified Patent Litigation System, ECLI:EU:C:2011:123, Opinion of 11 Mar. 2011, paras. 84-85.

${ }^{159}$ See ECJ, Case C-106/77, Simmenthal, ECLI:EU:C:1978:49, Judgment of 9 Mar. 1978; Case C-294/83, Les Verts, ECLI:EU: C:1986:166, Judgment of 23 Apr. 1986; Unified Patent Litigation System, Opinion 1/09, para. 80; Nial Fennelly, The National Judge as Judge of the European Union, in ThE Court of Justice AND the Construction of Europe 61 (Allan Rosas, Egils Levits \& Yves Bot eds., 2013).

${ }^{160}$ Lenaerts, On Judicial Independence, supra note 152 , at 162.

${ }^{161}$ For cases in which the ECJ actually assessed the independence of the referring entity, see e.g. ECJ, Case C-203/14, Consorci Sanitari del Maresme, ECLI:EU:C:2015:664, Judgment of 6 Oct. 2015, para. 19; Case C-222/13, TDC, ECLI:EU: C:2014:2265, Judgment of Oct. 2014, paras. 28-36; Joined Cases C-58 \& 59/13, Torresi, ECLI:EU:C:2014:2088, Judgment of 17 July 2014, paras. 18-25; Case C-506/04, Wilson, ECLI:EU:C:2006:587, Judgment of 19 Sept. 2006, paras. 49 et seq.; Case C-407/98, Abrahamsson and Anderson, ECLI:EU:C:2000:367, Judgment of 6 July 2000, paras. 29-37; Case C-103/ 97, Köllensperger and Atzwanger, ECLI:EU:C:1999:52, Judgment of 4 Feb. 1999, paras. 19-24; see generally MoRTEN Broberg \& Niels Fenger, Preliminary References to the European Court of Justice 62 et seq. (2 ${ }^{\text {nd }}$ ed., 2014).

${ }^{162}$ For a sharp critique of these demanding criteria, see the Opinion of Advocate General Jacobs at paras. 36-49, Case 50/00 P, Unión de Pequeños Agricultores (Mar. 21, 2002); Theodore Konstadinides, The Rule of LaW In the European Union: The InTERnal Dimension 111 (2017).

${ }^{163}$ See e.g. Takis Tridimas, Bifurcated Justice: The Dual Character of Judicial Protection in EU Law, in THE COURT OF JUSTICE AND THE CONSTRUCTION OF EUROPE, supra note 159, 367.

${ }^{164}$ See Koen Lenaerts, The Rule of Law and Coherence of the Judicial System of the European Union, 44 COMMON MKT. L. REV. 1625, 1629-30 (2007).

${ }^{165}$ See e.g. ECJ, Case C-432/05, Unibet, ECLI:EU:C:2007:163, Judgment of 13 Mar. 2007, paras. 40-43; Case C-213/89, Factortame I, ECLI:EU:C:1990:257, Judgment of 19 June 1990, paras. 19 et seq. See also Anthony Arnull, Remedies Before National Courts, in Oxford Principles of European Union LaW 1011 (Robert Schütze \& Takis Tridimas eds., 2018); Thomas Jaeger, Gerichtsorganisation und EU-Recht: Eine Standortbestimmung, 53 EuROPARECHT 611 (2018); José Luís da Cruz Vilaça, Le principe de l'effet utile du droit de l'Union dans la jurisprudence de la Cour, in THE COURT OF JUsTICE AND THE CONSTRUCTION OF EUROPE, supra note 159, 279, 300 et seq.

${ }^{166}$ For an interpretation placing ASJP in one line with established jurisprudence on the principle of loyal cooperation and effectiveness as enshrined in Art. 4(3) TEU, see Stephan Schill \& Christoph Krenn, Art. 4 EUV, in DAS RECHT DER EUROPÄISCHEN UNION, supra note 116, paras. 102 et seq.; Jaeger, supra note 165, at 615 et seq.
} 
the crucial passage of ASJP, the Court states that "Art. 19 TEU ... gives concrete expression to the value of the rule of law stated in Article 2". ${ }^{167}$ According to my understanding, this recourse to values lays the groundworks for the judicial applicability of Article 2 TEU. The Court implicitly rejected a self-standing application of Article 2 TEU and opted for a combined approach-it operationalizes Article 2 TEU through a specific provision of EU law (here Article 19(1)(2) TEU). ${ }^{168}$ How does this operationalization work and what is its effect?

Like the Charter, Article 19(1)(2) TEU's scope of application is a derived one. It only applies within the "fields covered by Union law". ${ }^{169}$ This, however, means that some kind of "Union law" is needed to trigger its scope. Since Article 2 TEU presumably lacks direct effect and is thus no self-standing provision either, it would probably not allow for such a triggering. ${ }^{170}$ Taken in isolation, both provisions are therefore not applicable: Article 19 because of its derived scope and Article 2 TEU because of its lacking direct effect. What could be a way out of this impasse?

At first glance, Article 19(1)(2) TEU would have to be triggered by other Union law (e.g. a directive or fundamental freedoms). In consequence, Article 2 TEU operationalized by Article 19(1)(2) TEU would depend on the scope of the triggering EU law and could not operate beyond that. ${ }^{171}$ Such a limitation, however, seems to severely neglect Article 2 TEU's foundational character and its unrestricted scope of application: The Member States are bound by it even in areas not covered by any (other) Union law. ${ }^{172}$ Limiting Article 2 TEU to the scope of other Union law would frustrate its overarching importance and deprive the recourse to Union values of any added-value.

And indeed, the CJEU does not seem to have limited the scope of Article 19(1)(2) TEU (operationalizing Article 2 TEU) to the scope of any other Union law applying. It established standards for practically any Member State court. How does the Court reach this conclusion?

According to my understanding, the combined reading of Article 2 TEU with a specific provision leads to a cumulation of their legal effects-a mutual amplification: While the specific provision of EU law (here Article 19 TEU) translates Article 2 TEU into a specific legal obligation, the operationalized Article 2 TEU triggers and determines the scope of application of the specific provision. ${ }^{173}$ In this interplay, each contributes what the other lacks-specificity and scope. As it is Article 2 TEU, which determines the scope, the operationalized obligations can apply beyond the scope of any other Union law to any Member State action. In this sense, the idea of mutual

\footnotetext{
${ }^{167}$ Associação Sindical dos Juízes Portugueses, Case C-64/16 at para. 32 (emphasis added). Similarly, see Commission v. Poland, C-619/18 R at para. 47 and para. 43: "EU law that implements those values"; Opinion of Advocate General Tanchev at para. 71, Case C-192/18, Commission v. Poland (June 20, 2019) (“[T]he second subparagraph of Article 19(1) TEU, a specific manifestation on the foundational values reflected in Article 2 TEU”); Opinion of Advocate General Tanchev at para. 77, Joined Cases C-585, 624 \& 625/18, Krajowa Rada Sądownictwa (June 27, 2019); Advocate General Tanchev at para. 92, Case C-558/18, Miasto Łowicz (Sept. 24, 2019) ("Article 19 TEU is a concrete manifestation of the rule of law, one of the fundamental values on which the European Union is founded under Article 2 TEU”).

${ }^{168}$ See also Armin von Bogdandy et al., Guest Editorial: A Potential Constitutional Moment for the European Rule of Law-The Importance of Red Lines, 55 Common MKT. L. ReV. 983 (2018).

${ }^{169}$ On Art. 19(1)(2) TEU as a self-standing provision, see Pech \& Platon, supra note 152, at 1838, 1848.

${ }^{170}$ For an attempt to construe a triggering relationship between Art. 2 TEU and the Charter (Art. 51(1) CFR), see András Jakab, Application of the Charter of Fundamental Rights by National Courts in Purely Domestic Cases, in THE ENFORCEMENT OF EU LAW AND VALUes, supra note 14, 252, 255.

${ }^{171}$ This would also be the case if Article 2 TEU was operationalized by other provisions, like Charter rights or a specific directive.

${ }^{172}$ See supra note 116 .

${ }^{173}$ See also Luke D. Spieker, From Moral Values to Legal Obligations-On How to Activate the Union's Common Values in the EU Rule of Law Crisis, MPIL Research PAPER No. 2018-24, at 25; von Bogdandy \& Spieker, supra note 60.
} 
amplification kills two birds with one stone: It allows for the judicial applicability of Article 2 TEU through a specific provision without losing its unrestricted scope.

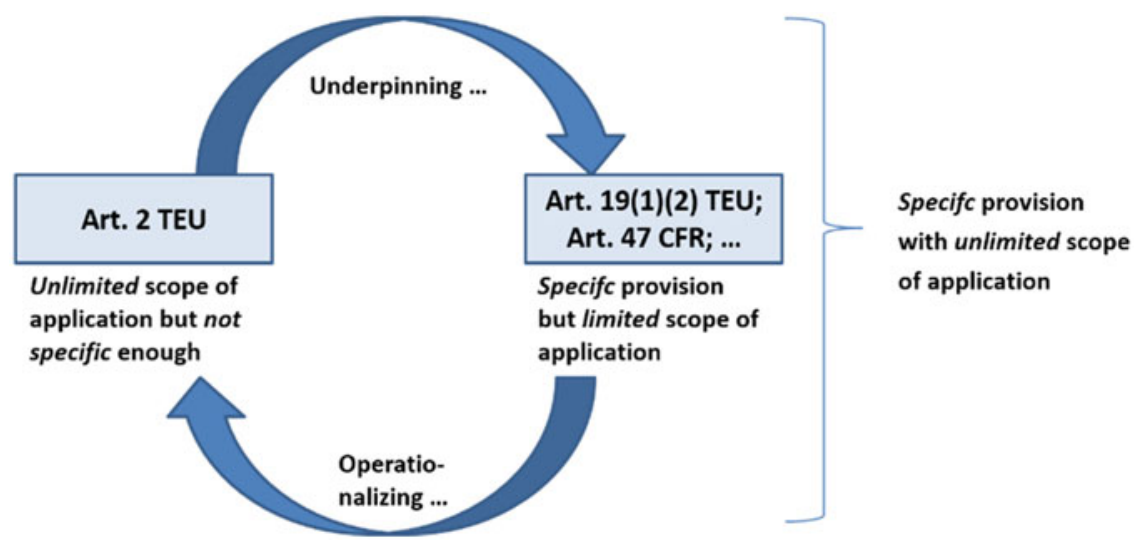

Figure 4: Mutual Amplification

Eventually, this approach could be extended to any norm of EU law containing a specific obligation and giving expression to a value enshrined in Article 2 TEU. As already mentioned, Article 2 TEU contains the values of "respect for human rights," democracy, and the rule of law. Since the Charter can be understood as a specific realization of these values, ${ }^{174}$ a mutual amplification of Article 2 TEU and Charter rights seems possible.

The Court's judgment in L.M. could be a first, careful step in this direction. As seen above, the CJEU assessed the conformity of a situation beyond the scope of Union law with the essence of a Charter right. ${ }^{175}$ Although the issue of an EAW is clearly within the scope of Union law as defined by Article 51(1) CFR, this is not the case for what is scrutinized under the Aranyosi-test. In L.M., neither the Polish judicial reforms nor the specific domestic criminal proceedings presented any apparent link to EU law-except for Article 2 TEU. One could of course argue that this review competence is a result of the specificities of mutual recognition regimes. ${ }^{176}$ Yet, similar to ASJP, the Court establishes a nexus between the essence of Article 47 CFR and Article 2 TEU:

Judicial independence forms part of the essence of the fundamental right to a fair trial ... which is of cardinal importance as a guarantee ... that the values common to the Member States set out in Article 2 TEU, in particular the value of the rule of law, will be safeguarded. ${ }^{177}$

In the same vein, the Court started to increasingly connect Article 2 TEU and Charter rights. In Tele2 Sverige, for example, the Court established a continuum between the freedom of expression under Article $11 \mathrm{CFR}$ and the value of democracy under Article 2 TEU. ${ }^{178}$ In light of these links,

\footnotetext{
${ }^{174}$ Voßkuhle, supra note 117 , at 114; Hilf \& Schorkopf, supra note 116, at para. 36; Thomas Schmitz, Die Charta der Grundrechte der Europäischen Union als Konkretisierung der gemeinsamen europäischen Werte, in DIE EUROPÄISCHE UNION ALS WERTEGEMEINSCHAFT 73, 84 (Dieter Blumenwitz et al. eds., 2005).

${ }^{175}$ See supra Section C.II.2.

${ }^{176}$ See supra Section C.II.1.

${ }^{177}$ Minister for Justice and Equality, Case C-216/18 PPU at para. 48. On this continuum between Art. 47 CFR and Art. 2 TEU, see also Wendel, supra note 100, at 27-29.

${ }^{178}$ ECJ, Joined Cases C-203 \& 698/15, Tele2 Sverige, ECLI:EU:C:2016:970, Judgment of 21 Dec. 2016, para. 93 (“That fundamental right, guaranteed in Article 11 of the Charter, constitutes one of the essential foundations of a pluralist, democratic society, and is one of the values on which, under Article 2 TEU, the Union is founded"). See also ECJ, Case C-163/10,
} 
one could argue that the concept of mutual amplification is not limited to the situation in ASJP, but instead open to all provisions of EU law giving concrete expression to Article 2 TEU values.

\section{Anticipating Objections and Advancing Rejoinders}

In sum, the Court's stance in ASJP could be interpreted as making the values in Article 2 TEU judicially applicable through a mutual amplification with a specific provisions of EU law. The decisions following ASJP reveal a twofold development. First, the Court is willing to scrutinize and sanction Member State actions under the operationalized Article 2 TEU. Although the CJEU refrained from finding any violation in ASJP, the judgment served as a stepping stone for the infringement proceedings against Poland. ${ }^{179}$ Second, the CJEU seems to develop the diffused and decentralized EU judicial network into a value monitoring and enforcement mechanism. Today, violations of operationalized Union values can reach the CJEU not only via infringement proceedings initiated by the Commission (constellation in Commission $v$. Poland) but also through preliminary reference procedures-either by "brave" national courts directly against national measures (constellation in ASJP) or by courts in other Member States assessing cooperation with backsliding Member States under mutual recognition regimes (constellation in L.M.).

Without a doubt, the proposed reading of ASJP and its progenies leads to a considerable development of the law. It seems to immensely extend the scope of Union law and the Court's jurisdiction. Indeed, no area of the Member States seems to escape the obligations stemming from Article 2 TEU. As such, Article 2 TEU could become the core of a European Constitution threatening the federal equilibrium established by the Treaties. Therefore, any proposal of placing an activated Article 2 TEU in the hands of the CJEU will most certainly raise doubts and criticism. The following section aims at anticipating some of this critique by referring to one of Luxembourg's most accomplished national counterparts-the Bundesverfassungsgericht ("BVerfG").

\section{Framing Possible Objections}

Generally, it seems uncontested that EU primary law is characterized by a special, evolutive dynamic $^{180}$ and has to be interpreted accordingly. ${ }^{181}$ Due to the partial incompleteness of the EU legal order, the creative judicial development of the law ${ }^{182}$ has been an accepted feature of the CJEU's legal reasoning since the very beginning. ${ }^{183}$ This must apply especially in situations of new and unprecedented challenges that threaten the EU's very foundations.

Patriciello, ECLI:EU:C:2011:543, Judgment of 6 Sept. 2011, para. 31. See further the connection between Art. 47 CFR and Art. 2 TEU in ECJ, Case C -72/15, Rosneft, ECLI:EU:C:2017:236, Judgment of 28 Mar. 2017, paras. 72-73.

${ }^{179}$ See supra note 28 .

${ }^{180}$ See, for example, the characterization as "Wandelverfassung” by Hans-Peter Ipsen, Die Verfassungsrolle des Europäischen Gerichtshofs für die Integration, in DER EUROPÄISCHE GERICHTSHOF ALS VERFASSUNGSGERICHT UND RECHTSSCHUTZINSTANZ 29, 32, 51 (Jürgen Schwarze ed., 1983).

${ }^{181}$ Sebastian A. E. Martens, Methodenlehre des Unionsrechts 475 (2013); Giulio Itzcovich, The Interpretation of Community Law by the European Court of Justice, 10 German L.J. 537, 549 (2009); Joxerramon BengoetXea, The LEgal ReAsoning of THE EuROPEAN COURT OF Justice 251 (1993).

${ }^{182}$ The CJEU does not distinguish between "interpretation" ("Auslegung") and "development of the law" ("Rechtsfortbildung"), see Martens, supra note 181, at 503; Matthias Jestaedt, Luxemburger Richterrecht, in Gouvernement Des Juges-Fluch Oder Segen 21, 33 (Christian Hillgruber ed., 2014).

${ }^{183}$ See BVerfG, 2 BvR 687/85, Kloppenburg, Judgment of 8 April 1987, paras. 58-60. See also Lecourt, supra note 17, at 236; Dehousse, supra note 17, at 70; Ulrich Everling, On Judge-Made Law of the European Community's Courts, in JUDICIAL Review in European Union Law 29 (David O'Keeffe ed., 2000); Koen Lenaerts \& Kathleen Gutman, "Federal Common Law" in the European Union, 54 AM. J. CoMP. L. 1, 7 (2006). 
There are, however, two key limits to such a judicial development of the law, which the BVerfG sketched out in Honeywell: ${ }^{184}$ Horizontally, the Court should respect the inter-institutional separation of powers. Accordingly, "[t]he Court of Justice is ... not precluded from refining the law by means of methodically bound case-law" respecting its judicial function. ${ }^{185}$ "[A]s long as the Court of Justice applies recognised methodological principles", the judicial development of the law by the CJEU has to be accepted. ${ }^{186}$ Vertically, a "major limit on further development of the law by judges at Union level is the principle of conferral" ${ }^{187}$ Under this premise, it is essential to anchor the proposed reading of ASJP and the idea of mutual amplification carefully in the Court's case law and established methods of legal reasoning (III.2.). At the same time, its impact must be strictly limited in order to safeguard the Union's federal equilibrium (III.3.).

\section{A Methodologically Unsound Concept?}

Despite evident difficulties in agreeing on a common European legal methodology, ${ }^{188}$ the CJEU's interpretation generally revolves around "the spirit, the general scheme and the wording of the Treaty" 189 and concentrates especially on a mixture of systematic and teleological considerations. ${ }^{190}$ On one hand, the Court can consider the telos of a respective provision itself. On the other hand, it can refer to a telos detached from said provision by referring to objectives or principles of the EU legal order. This second type could be described as systematic or metateleological interpretation. ${ }^{191}$ In this light, there is a twofold, interlocking methodological justification for the idea of mutual amplification between Article 2 TEU and a specific provision of EU law.

First, the Court can rely on a teleological, concretizing, or gap-filling interpretation of Article 2 TEU itself-a practice accepted by the BVerfG as a methodologically sound, judicial endeavor. ${ }^{192}$ Specifying the obligations enshrined in Article 2 TEU by relying on existing provisions of the acquis not only provides such specificity, but is also much more restrained than filling the gap solely based on case law and praetorian principles. ${ }^{193}$ In doing so, a parallel could be drawn to the Court's case law on Union objectives. Although these objectives do not have any direct effect, ${ }^{194}$ the Court found ways to make them judicially applicable. It stated that the Union's objectives "are necessarily applied in combination with the respective chapters of the EC Treaty intended to give effect to those principles and objectives". ${ }^{195}$

\footnotetext{
${ }^{184}$ BVerfG, 2 BvR 2661/06, Honeywell, Order of 6 July 2010. See also Lenaerts \& Gutman, supra note 183 , at 45 et seq.; Christian Calliess, Grundlagen, Grenzen und Perspektiven europäischen Richterrechts, 58 NEUE JURISTISCHE WOCHENSCHRIFT 929, 930 (2005); Wulf-Henning Roth, Verfassung und europäische Methodenlehre, 75 RABEL J. COMP. \& INT'L PRIV. L. 787, 834 (2011).

${ }^{185}$ BVerfG, 2 BvR 2661/06, Honeywell, Order of 6 July 2010, paras. 62, 64 (emphasis added).

${ }^{186} \mathrm{BVerfG}, 2$ BvE 13/13, OMT, Judgment of 21 June 2016, para. 161 (emphasis added).

${ }^{187}$ Id. at para. 65.

${ }^{188}$ Philipp Dann, Thoughts on a Methodology of European Constitutional Law, 6 GERMAN L.J. 1453 (2005); on EU private law, see Holger Fleischer, Europäische Methodenlehre: Stand und Perspektiven, 75 RABEL J. COMP. \& INT'L PRIV. L. 700 (2011).

${ }^{189}$ Van Gend den Loos, Case C-26/62. For a typology, see GunNar BeCK, The Legal Reasoning of the Court of JustiCE 147 et seq. (2013); Koen Lenaerts \& José A. Gutiérrez-Fons, To Say What the Law of the EU Is: Methods of Interpretation and the European Court of Justice, 20 ColuM. J. EUR. L. 3 (2014); Itzcovich, supra note 181.

${ }^{190}$ See e.g. ECJ, Case 283/81, Cilfit, ECLI:EU:C:1982:335, Judgment of 6 Oct. 1982, para. 20. See also Pescatore, supra note 17 , at 88 ("decisive criterion of every legal interpretation").

${ }^{191}$ Miguel Poiares Maduro, Interpreting European Law, 1 EUR. J. LEG. STUD. 1, 5 (2007). On the difficulties to separate teleological and systemic interpretation, see Lenaerts \& Gutiérrez-Fons, supra note 189, at 17.

${ }^{192}$ BVerfG, 2 BvR 2661/06, Honeywell, Order of 6 July 2010, para. 64: "There is particular reason for further development of the law by judges where programmes are fleshed out, gaps are closed ...."

${ }^{193}$ On the necessity to fill this "value-gap", see the introduction of this contribution.

${ }^{194}$ See e.g. ECJ, Case C-339/89, Alsthom Atlantique, ECLI:EU:C:1991:28, Judgment of 21 Jan. 1991, paras. 8-9. See also ERT, Case C-260/89, paras. 39-40.

${ }^{195}$ See e.g. ECJ, Case C-484/08, Caja de Ahorros, ECLI:EU:C:2010:309, Judgment of 3 June 2010, para. 46 (emphasis added); Case C-293/03, My, ECLIEU:C:2004:821, Judgment of 16 Dec. 2004, para. 29.
} 
Second, the Court can employ a systematic or meta-teleological interpretation of the specific provision operationalizing Article 2 TEU (e.g. Article 19(1)(2) TEU, Charter rights or any other provision giving specific expression to Article 2 TEU). Under this method, the specific provision would be interpreted in light of the Union's founding values as enshrined in Article 2 TEU. In case of provisions, which have no derived but nonetheless a limited scope of application (e.g. cross-border requirements), this could lead to a careful teleological reduction of their restricted scope as far as Article 2 TEU values are at stake. ${ }^{196}$ Although there are arguably no hierarchies in EU primary law, ${ }^{197}$ some provisions-like objectives - seem to have been treated as primus inter pares and served as guiding stars for its interpretation. ${ }^{198}$ After Lisbon, objectives seem to take a back seat behind the Union's common values. As some commentators noted, Article 2 TEU "symbolizes a paradigm shift from a legal entity that, in the first place, exists to strive for certain goals to one which, above all, expounds what it stands for." 199 This shift should find its expression in the Court's legal methodology. Hence, it does not seem far-fetched to propose a new kind of meta-teleological interpretation-not in light of the Union's objectives, but in light of its common values: An axiological interpretation. ${ }^{200}$

Eventually, the idea of a mutual amplification - two mutually complementing and reinforcing provisions-is not unprecedented in the Court's case law. In a rather recent line of cases, the Court had to decide on the interplay of rights stemming from directives and Charter rights in horizontal situations between private parties. These cases concerned the question of whether a national provision in a case between two individuals conformed with EU law-first with rights stemming from specific directives and second with EU fundamental rights. Directives do not apply horizontally. ${ }^{201}$ The fundamental rights at issue apply horizontally ${ }^{202}$ - yet they are accessory to the scope of Union law (Art. 51(1) CFR) and apply only in case their scope is triggered by the directive. ${ }^{203}$ Thus, taken in isolation, neither of them is applicable. The Court, however, relied on a creative solution based on the notorious Mangold judgment. ${ }^{204}$ Taken together, both the directive as well as the fundamental right contribute to what the other lacks: Scope and horizontal effect. The directive, although not directly applicable, has "the effect of bringing within the scope of European Union law the national legislation at issue". ${ }^{205}$ Once the scope is triggered, it is the

\footnotetext{
${ }^{196}$ On this method, see András Jakab, Judicial Reasoning in Constitutional Courts: A European Perspective, 14 GERMAN L. J. 1215, 1221 (2013); on the high burdens for justifying its use, see Jakab, supra note 122, at 19.

${ }^{197}$ On this discussion, see Allan Rosas \& Lorna ARMati, EU CONSTitutional Law Chapter 5 ( $3^{\text {rd }}$ ed., 2018); Andreas von Arnauld, Normenhierarchien innerhalb des primären Gemeinschaftsrechts, 38 EUROPARECHT 191 (2003); Martin Nettesheim, Normenhierarchien im EU-Recht, 41 EUROPARECHT 737 (2006). Hinting towards the existence of hierarchies, see Kadi, Case C-402/05 P at para. 303; Opinion 1/91, EEA, ECLI:EU:C:1991:490, Opinion of 14 Dec. 1991, para. 6.

${ }^{198}$ See e.g. ECJ, Case C-85/76, Hoffmann-La Roche, ECLI:EU:C:1979:36, Judgment of 13 Feb. 1979, para. 125; Case C-53/81, Levin, ECLI:EU:C:1982:105, Judgment of 23 Mar. 1982, para. 15; Case C-6/72, Continental Can, ECLI:EU:C:1973:22, Judgment of 21 Feb. 1973, para. 24.

${ }^{199}$ Larik, supra note 123, at 951. See also Jospeh H.H. Weiler, Integration Through Fear, 23 EUR. J. INT'L L. 1 (2012) describing a shift "from something that Europe does to something that Europe is".

${ }^{200}$ On such a "value-oriented" interpretation, see von Bogdandy \& Spieker, supra note 60; Michael Potacs, Wertkonforme Auslegung des Unionsrechts, 51 EUROPARECHT 164 (2016); Calliess, supra note 117. With regard to the Charter, see Thomas Ritter, Neue Werteordnung für die Gesetzesauslegung durch den Lissabon-Vertrag, 63 NEUE JURISTISCHE WOCHENSCHRIFT 1110 (2010).

${ }^{201}$ See recently ECJ, Case C-122/17, Smith, ECLI:EU:C:2018:631, Judgment of 7 Aug. 2018, paras. 42-44.

${ }^{202}$ This has been confirmed by the ECJ in Bauer, Case C-569/16 at paras. 79-90; Max-Planck-Gesellschaft, Case C-684/16 at paras. 75-79; Egenberger, Case C-414/16 at para. 76; Cresco Investigation, Case C-193/17 at para. 76; Association de médiation sociale, C-176/12 at para. 47. With regard to general principles, see ECJ, Case C-441/14, Danks Industri, ECLI:EU:C:2016:278, Judgment of 19 Apr. 2016, para. 27; Case C-555/07, Kücükdeveci, ECLI:EU:C:2010:21, Judgment of 19 Jan. 2010, para. 51; Case C-144/04, Mangold, ECLI:EU:C:2005:709, Judgment of 22 Nov. 2005, para. 77.

${ }^{203}$ On Article 51(1) CFR requiring an obligation of EU law actually applying in the case at hand, see supra note 49.

${ }^{204}$ Mangold, Case C-144/04 at para. 75; Kücükdeveci, Case C-555/07 at para. 23; critically BVerfG, 2 BvR 2661/06, Honeywell, Judgment of 6 July 2010; Danish Supreme Court, 15/2014, Ajos, Judgment of 6 Dec. 2016.

${ }^{205}$ Kücükdeveci, Case C-555/07 at para. 25. See also Bauer, Case C-569/16 at para. 53; Max-Planck-Gesellschaft, Case C-684/ 16 at para. 50 .
} 
Charter right that applies horizontally in the case at hand. To add another layer to this complex interplay, the Court applies the Charter right (or the general principle) in a manner that is exactly equivalent to the right enshrined in the directive. This becomes most apparent in Kücükdeveci, where the Court stated that Directive 2000/78 "gives specific expression" to the general principle of non-discrimination. ${ }^{206}$ The Court de facto applied the Directive as the principle's (or right's) specific expression. ${ }^{207}$ As such, this reasoning is a perfect example for the cumulation of legal effects sketched out above: The general principle allows for the horizontal application, while the Directive triggers the scope of Union law and provides for specificity.

\section{Pretext for a Power Grab?}

Naturally, the bold reading of the Court's case law as proposed above has the potential of severely upsetting the Union's federal equilibrium epitomized by Articles 4(2) or 5(1) TEU or Article 51(1) CFR. ${ }^{208}$ Therefore, it is essential to put safeguards in place ensuring that Article 2 TEU does not become the "pretext for a power grab". ${ }^{209}$ These essential safeguards, however, should not be applied in a way that frustrates the respect for Article 2 TEU values either. Both considerations have to be carefully balanced against each other. In my view, the outcome of this balancing exercise could be a threefold limitation ensuring Article 2 TEU's function and simultaneously providing a safety net for the federal bargain.

\subsection{Limiting the Obligations Enshrined in Article 2 TEU}

First, Article 2 TEU must be interpreted in a restrictive manner as being triggered only in exceptional situations. On the one hand, Article 2 TEU cannot impose high standards upon the Member States, since such an interpretation could not be squared with the legally guaranteed constitutional autonomy of the Member States. ${ }^{210}$ Concerning the value of "respect for human rights", some have proposed operating with the concept of "essence". ${ }^{211}$ As far as the essence of Charter rights is concerned, they are also protected as values under Article 2 TEU, while Article 51(1) CFR continues to delimit the application of the full fundamental right acquis. On the other hand, Article 2 TEU can hardly force detailed obligations upon the Member States, because this would ignore the actually existing constitutional pluralism in the Union. Due to the practically countless possibilities of how to bring the abstract values to life, Article 2 TEU cannot-from a mere practical

\footnotetext{
${ }^{206}$ Kücükdeveci, Case C-555/07 at para. 21; Cresco Investigation, Case C-193/17 at para. 75; Max-Planck-Gesellschaft, Case C-684/16 at para. 72; Bauer, Case C-569/16 at para. 83; Egenberger, Case C-414/16 at paras. 47, 75; Dansk Industri, Case C-441/14 at para. 35. See also ECJ, Case C-447/09, Prigge, ECLI:EU:C:2011:573, Judgment of 13 Sept. 2011, para. 48; Case C-297-298/10, Hennigs and Mai, ECLI:EU:C:2011:560, Judgment of 8 Sept. 2011, para. 68.

${ }^{207}$ See ECJ, Case C-132/11, Tyrolean Airways, ECLI:EU:C:2012:329, Judgment of 7 June 2012, para. 23 (“ . . to be examined solely in the light of Directive 2000/78") (emphasis added).

${ }^{208}$ See e.g. the arguments of Poland in Commission v. Poland, Case C-619/18 R at paras. 39-40.

${ }^{209}$ Dimitry Kochenov, The EU and the Rule of Law - Naïveté or a Grand Design?, in CONSTITUTIONALISM AND THE RULE OF LAW 419, 443 (Maurice Adams, Anne Meuwese \& Ernst Hirsch Ballin eds., 2017).

${ }^{210}$ For similar conceptions, see Voßkuhle, supra note 117, at 116-117; Werner Schroeder, The European Union and the Rule of Law-State of Affairs and Ways of Strengthening, in STRENGTHENING THE RulE OF LAW, supra note 14, 3, 11 ("minimum standards"); Gabriel Toggenburg \& Jonas Grimheden, Managing the Rule of Law in a Heterogeneous Context, in Strengthening the RUle of LAW, supra note 14, 221 ("minimum constitutional cohesion"). See also European Convention, supra note 116 , at 11 :
}

This Article can thus only contain a hard core of values meeting two criteria at once: on one hand, they must be so fundamental that they lie at the very heart of a peaceful society practicing tolerance, justice and solidarity; on the other hand, they must have a clear non-controversial legal basis so that the Member States can discern the obligations resulting therefrom.

${ }^{211}$ von Bogdandy et al., supra note 22, at 509 et seq. On the notion of "essence," see further Maja Brkan, The Concept of Essence of Fundamental Rights in the EU Legal Order: Peeling the Onion to Its Core, 14 EuR. ConsT. L. REV. 332 (2018); Koen Lenaerts, Limits on Limitations: The Essence of Fundamental Rights in the EU, 20 GERMAN L.J. 779 (2019). See generally Special Issue 20 GERMAN L.J. 763 (2019). 
perspective-be understood as containing very detailed obligations. ${ }^{212}$ Accordingly, Article 2 TEU's high degree of abstraction necessarily correlates with a lower degree of review by the Court. Where does that leave us? One feasible solution could be to understand Article 2 TEU as establishing only a regime of "red lines". ${ }^{213}$ On a conceptual level, Article 2 TEU would determine negatively what is not allowed, without positively determining how things should be instead. In a nutshell, the Court should apply Article 2 TEU only in exceptional situations and only in the form of "red lines".

\subsection{Limiting the EU's Competence}

Second, I argue that the Union's "Verbandskompetenz" (its competence as a legal order) to enforce Member State's Article 2 TEU compliance beyond the scope of (any other) Union law is limited to the substantive thresholds of Article 7 TEU. Indeed, the only provision explicitly empowering the EU legal order to enforce EU values or sanction violations thereof beyond the scope of (any other) Union law is Article 7 TEU. Hence, this provision contains a strong indication that the EU's Verbandskompetenz is limited at least to the substantive thresholds triggering Article 7 TEU (a "serious and persistent breach"). ${ }^{214}$ This could provide the starting point for a workable restriction operating in form of a sliding scale: The more or the clearer a situation falls within the scope of other EU law, the more the EU and the less the respective Member State is affected. This means that in case of a clear link to EU law, every violation of Article 2 TEU values can be sanctioned by EU institutions (e.g. under the Charter). If the link is weaker or nonexistent, it approaches the confines of Article 7 TEU. To assess and sanction every violation in such situations would exceed the EU's Verbandskompetenz. Therefore, the more the situation departs from the scope of Union law and comes solely under Article 2 TEU, the more a violation must reach the substantive thresholds of Article 7, and the more it must constitute a "serious and persistent" breach in order to be invoked before the CJEU. This sliding scale could be visualized as follows:

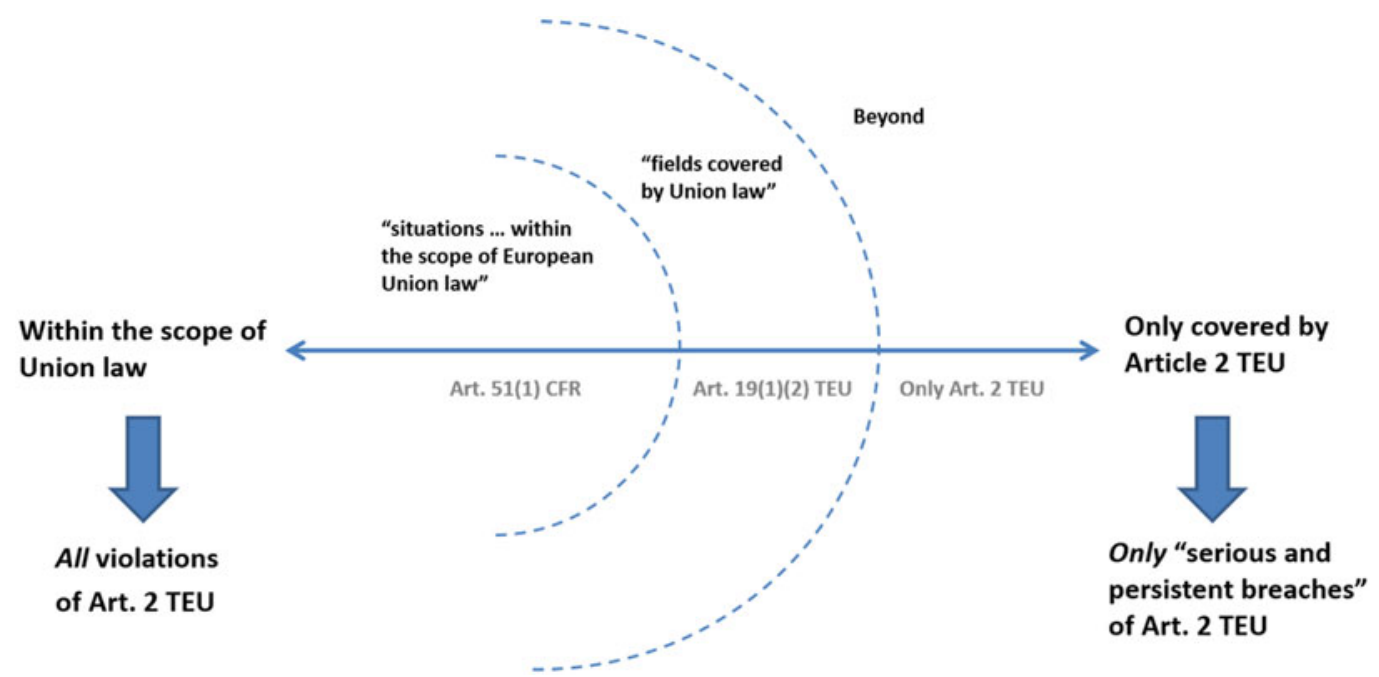

Figure 5: Sliding scale

\footnotetext{
${ }^{212}$ See also Felix Hanschmann, Der BEgrifF DER HOMOgENITÄT IN DER VerfassungsLeHRE UND EUROPARECHTSWISSENSCHAFT 248 (2008); von Bogdandy, supra note 117, at 40.

${ }^{213}$ von Bogdandy et al., supra note 168.

${ }^{214}$ See also Council of the European Union, Opinion of the Legal Service, supra note 116, at para. 17.
} 


\subsection{Limiting the CJEU's Competence}

Finally, as proposed by the Reverse Solange doctrine, the Court's "Organkompetenz" to review Article 2 TEU value compliance in the Member States could be subject to a presumption of conformity accompanied by a high threshold for its rebuttal. Such a threshold could be fixed on the level of systemic deficiencies-a notion which is well-established throughout the European legal space. ${ }^{215}$ Therefore, simple and isolated infringements upon the values enshrined in Article 2 TEU will not suffice to rebut the proposed presumption. The justification for such a presumption could be derived from the principle of mutual trust. Although mutual trust has initially only been invoked horizontally between the Member States, ${ }^{216}$ it is not excluded in the vertical relationship of EU and Member States. Mutual trust is based on or at least intrinsically linked to the principle of loyal and sincere cooperation in Article 4(3) TEU. ${ }^{217}$ This can also be derived from the Court's case law. ${ }^{218}$ The principle of mutual loyalty, however, expressly extends to Union institutions and hence the CJEU as well. ${ }^{219} \mathrm{~A}$ similar trend could be predicted for the principle of mutual trust.

\section{E. Conclusion}

In entering the European Union and opening their respective legal orders for direct effect and primacy, the Member States simultaneously accepted an openness towards internal developments and decisions taken by other Member States. The EU does not only extend the transnational reach of each Member State, but also creates a situation of mutual vulnerability. ${ }^{220}$ Internal developments in one Member State can lead to spill-over effects in all other Member States. The complex network of cooperation created by the European Union is not only enabling, it is transmitting and intensifying these effects. Especially through the introduction of majority decisions in the Council, each Member State partially and indirectly governs all others. As such, the EU is underpinned by an "all-affected principle". 221

As Commissioner Jourova put it: "the EU is like a chain of Christmas lights. When one light goes off, others don't light up and the chain is dark."222 This holds particularly true for the EU judicial space. In the words of Koen Lenaerts,

\footnotetext{
${ }^{215}$ See von Bogdandy \& Spieker, supra note 60; Armin von Bogdandy \& Michael Ioannidis, Systemic Deficiency in the Rule of Law, 51 Common MKT. L. Rev. 59 (2014).

${ }^{216}$ Associação Sindical dos Juízes Portugueses, Case 64/16 at para. 30; Minister for Justice and Equality, Case 216/18 PPU at para. 35.

${ }^{217}$ Meyer, supra note 77, at 179; Christine Janssens, The Principle of Mutual Recognition in Eu Law 151 (2014); more nuanced Maria Fartunova, La Coopération loyale vue sous le prisme de la reconnaissance mutuelle: quelques réflexions sur les fondements de la construction européenne, 52 CAHIERS DE DroIT EuROPÉEN 193 (2016); on the intrinsic link between the principles of mutual trust and loyalty, see Sacha Prechal, Mutual Trust Before the Court of Justice of the European Union, 2 European PAPERs 75, 90-92 (2017); Damien Gerard, Mutual Trust as Constitutionalism?, in MAPPING MUTUAL TRUST 69, 76 (Evelien Brouwer \& Damien Gerard eds., 2016). But see Lenaerts, supra note 77, at 807, who derives mutual trust from the principle of equality between the Member States.

${ }^{218}$ See e.g. ECJ, Case C-5/94, Hedley Lomas, ECLI:EU:C:1996:205, Judgment of 23 May 1996, para. 19. See also Opinion of Advocate General Ruiz-Jarabo Colomer at para. 45, Case C-297/07, Bourquain (Apr. 8, 2008) ("experience shows that mutual trust applies ... fulfilling a role similar to that of loyal cooperation").

${ }^{219}$ See the wording of Article 4(3) TEU. See further ECJ, Case C-339/00, Ireland v. Commission, ECLI:EU:C:2003:545 Judgment of 16 Oct. 2003, para. 72; Case C-197/13, Spain v. Commission, ECLI:EU:C:2014:2157, Judgment of 4 Sept. 2014 , para. 87.

${ }^{220}$ For an analysis, see Alexander Somek, The Argument from Transnational Effects I, 16 EUR L.J. 315 (2010).

${ }^{221}$ See e.g. Closa, supra note 13 , at 18.

${ }^{222}$ Vera Jourova, Speech at the High-level Seminar Finland 100 years-Finnish and European perspectives to the Rule of Law (Oct. 31, 2017), ec.europa.eu/commission/commissioners/2014-2019/jourova/announcements/speech-commissionerjourova-high-level-seminar-finland-100-years-finnish-and-european-perspectives_en.
} 
It is the ... effect of supranational and transnational justice that creates a 'chain of justice' in Europe where national courts are to engage in a dialogue with the ECJ as well as with each other. Thus, where a national court ceases to be independent, a shackle of that chain is broken and justice in Europe as a whole is inevitably weakened. ${ }^{223}$

Therefore, it is of utmost importance to secure Member States' adherence to the Union's common values as an underlying basis and essential safety net on which cooperation can take place.

The last two years have shown that the Court seems more than willing to protect this common value basis against illiberal developments in the Member States. The judgment in ASJP especially represents a veritable stepping stone towards a strong "union of values" —a judgment on par with van Gend en Loos, Costa/ENEL, or Les Verts. ${ }^{224}$ Its groundbreaking potential cannot be overemphasized. With ASJP, the Court achieved to breathe life into the Union's common values-it paved the way for their judicial application in the EU value crisis. In sum, the Court's stance in ASJP could be understood as making Article 2 TEU judicially applicable by operationalizing it through specific provisions of EU law without, however, losing its unrestricted scope. Due to this mutual amplification, any Member State act can be scrutinized under the operationalized Article 2 TEU-albeit under very restrictive conditions and only in very exceptional circumstances. As such, Article 2 TEU has become the Archimedean point for judicial proceedings against backsliding Member States.

Eventually, however, judicial proceedings are only one part of the solution. As the late ErnstWolfgang Böckenförde concluded in his famous dictum, any legal order draws eventually on preconditions it cannot itself guarantee. ${ }^{225}$ This applies especially to the blossoming European union of values. Commissioner Jourova put it in a nutshell: "We will have to decide ... what ... really holds us together. I am among those who believe that values are ... that glue."226

\footnotetext{
${ }^{223}$ Koen Lenaerts, On Judicial Independence and the Quest for National, Supranational and Transnational Justice, Speech at the National Congress of the Polish Bar (May 20, 2018), www.krs.pl/admin/files/poland_may_2017.pdf.

${ }^{224}$ For this perception, see Koen Lenaerts, Upholding the Rule of Law within the EU, Keynote Address at the RECONNECT Conference on Democracy and the Rule of Law in the EU (July 5, 2019), reconnect-europe.eu/events/conference-2019/.

${ }^{225}$ Ernst-Wolfgang Böckenförde, The Rise of the State as a Process of Secularization, in RELIGION, LAW, AND DEMOCRACY. Selected Writings (Mirjam Künkler \& Tine Stein eds., forthcoming 2020).

${ }^{226}$ Jourova, supra note 222
} 